\title{
Ultrastructural Heterogeneity of Carbonaceous Material in Ancient Cherts: Investigating Biosignature Origin and Preservation
}

\author{
Yuangao Qu, Anders Engdahl, ${ }^{2}$ Shixing Zhu, ${ }^{3}$ Vivi Vajda,,5 and Nicola McLoughlin ${ }^{1}$
}

\begin{abstract}
Opaline silica deposits on Mars may be good target sites where organic biosignatures could be preserved. Potential analogues on Earth are provided by ancient cherts containing carbonaceous material (CM) permineralized by silica. In this study, we investigated the ultrastructure and chemical characteristics of CM in the Rhynie chert (c. $410 \mathrm{Ma}$, UK), Bitter Springs Formation (c. $820 \mathrm{Ma}$, Australia), and Wumishan Formation (c. $1485 \mathrm{Ma}$, China). Raman spectroscopy indicates that the CM has experienced advanced diagenesis or lowgrade metamorphism at peak metamorphic temperatures of $150-350^{\circ} \mathrm{C}$. Raman mapping and micro-Fourier transform infrared (micro-FTIR) spectroscopy were used to document subcellular-scale variation in the CM of fossilized plants, fungi, prokaryotes, and carbonaceous stromatolites.

In the Rhynie chert, ultrastructural variation in the CM was found within individual fossils, while in coccoidal and filamentous microfossils of the Bitter Springs and formless CM of the Wumishan stromatolites ultrastructural variation was found between, not within, different microfossils. This heterogeneity cannot be explained by secondary geological processes but supports diverse carbonaceous precursors that experienced differential graphitization. Micro-FTIR analysis found that CM with lower structural order contains more straight carbon chains (has a lower $R_{3 / 2}$ branching index) and that the structural order of eukaryotic CM is more heterogeneous than prokaryotic CM.

This study demonstrates how Raman spectroscopy combined with micro-FTIR can be used to investigate the origin and preservation of silica-permineralized organics. This approach has good capability for furthering our understanding of CM preserved in Precambrian cherts, and potential biosignatures in siliceous deposits on Mars. Key Words: Rhynie chert-Bitter Springs Formation-Wumishan Formation-Raman spectroscopyMicro-FTIR—Carbonaceous material-Fossil. Astrobiology 15, 825-842.
\end{abstract}

\section{Introduction}

$\mathbf{C}$ ARBONACEOUS MATERIAL (CM) preserved in ancient sedimentary rocks provides an important textural and geochemical record of the history of life on Earth (e.g., House et al., 2000; Des Marais, 2001; Schidlowski, 2001; Grassineau et al., 2006; Hayes and Waldbauer, 2006; Schopf, 2006). However, increasing degrees of metamorphism can modify and mask carbonaceous biosignatures, and make them more difficult to interpret (e.g., van Zuilen et al., 2007; Qu et al., 2012). The structural order of CM can be used to assess the quality of preservation and, in some instances, identify varia- tion in the organic precursor (Franklin, 1951; Bernard et al., 2010; Olcott Marshall et al., 2014; Sforna et al., 2014a). During postdepositional processes, organic matter experiences bacterial degradation, diagenesis, catagenesis, and metamorphism such that it gradually loses functional groups and heteroatoms, its molecular structure is rearranged to a higher order, and it is finally transformed from disordered kerogen to highly ordered graphite with hexatomic rings at high metamorphic grades (e.g., Buseck et al., 1987; Bustin et al., 1995). Vibrational spectroscopy techniques, in particular Raman spectroscopy and Fourier transform infrared (FTIR) spectroscopy, can be used to investigate $\mathrm{CM}$ in sedimentary rocks (e.g., Olcott

\footnotetext{
${ }^{1}$ Department of Earth Science and Centre for Geobiology, University of Bergen, Norway.

${ }^{2}$ MAX IV Laboratory, Lund University, Sweden.

${ }^{3}$ Tianjin Institute of Geology and Mineral Resources, CGS, China.

${ }^{4}$ Department of Palaeobiology, Swedish Museum of Natural History, Sweden.

${ }^{5}$ Department of Geology, Lund University, Sweden.
} 
Marshall and Marshall, 2014, and references therein). CM can be identified by its characteristic Raman spectrum with two peaks at $1350 \mathrm{~cm}^{-1}$ and $1600 \mathrm{~cm}^{-1}$, and further properties such as band width and the intensity ratio of these two bands (see Section 2 below) can be used to evaluate the structural order and size of graphene layer (e.g., Tuinstra and Koenig, 1970; Kouketsu et al., 2014). FTIR spectroscopy can provide complementary information about the functional groups attached to the carbon chains, the chemical structure, and bonding environment (e.g., Mayo et al., 2004). In this study, we applied a combined vibrational spectroscopy approach to investigate well-preserved carbonaceous biosignatures preserved in chert (siliceous sediments), with a view to develop a tool for astrobiological exploration.

Raman spectroscopy has been widely applied to investigate carbonaceous biosignatures in the early rock record, and there are several factors that control the structural order of $\mathrm{CM}$ in sedimentary rocks, including the nature of the carbon precursor (Franklin, 1951; Bernard et al., 2010; Sforna et al., 2014a), metamorphic temperatures (Beyssac et al., 2002; Rahl et al., 2005; Lahfid et al., 2010; Kouketsu et al., 2014), deformation and shear forces (Ross and Bustin, 1990; Aoya et al., 2010), geological fluids, in particular hydrothermal circulation (Wopenka and Pasteris, 1993, and references therein), graphite deposition from fluids (Luque et al., 2009; Lepland et al., 2011; Galvez et al., 2013), and mineral templating effects (van Zuilen et al., 2012). Each of these factors needs to be investigated in turn and distinguished before the variations in carbonaceous ultrastructure can be interpreted in terms of biological processes. Raman spectroscopy has been used to test the syngenicity of carbonaceous biosignatures, in other words to establish whether they are indigenous to the host rock by comparing the ultrastructure and hence thermal maturity of the carbonaceous biosignature to carbon in the surrounding matrix (e.g., Javaux et al., 2010). This is an important criterion for evaluating biogenicity, especially in the early rock record where postdepositional fluid migration can introduce relatively young organic compounds. Raman spectroscopy alone cannot be used to demonstrate a biogenic origin for CM (e.g., Pasteris and Wopenka, 2003), and additional information provided by other techniques such as gas chromatography-mass spectrometry (GC-MS), FTIR, and/ or carbon isotopes by secondary-ion mass spectroscopic (SIMS) analysis is required to definitively identify a biosignature (e.g., Olcott Marshall et al., 2009; Oehler and Cady, 2014; Marshall and Olcott Marshall, 2014). In this study, Raman mapping and micro-FTIR were combined to study the same carbonaceous features at comparable scales.

Vibrational spectroscopy has been used to investigate fossilized CM in (meta)-sedimentary rocks with high spatial (micrometer-scale) resolution by several workers, and some key studies will be summarized here. Raman imaging can be used to map in two and three dimensions the morphology of microfossils by using the intensity of bands at 1350 or $1600 \mathrm{~cm}^{-1}$ of spectra to reveal subcellular structures $(e . g$., Schopf and Kudryavtsev, 2005, 2009), although only the band at $1600 \mathrm{~cm}^{-1}$ is used if the sample contains hematite (Marshall and Olcott Marshall, 2011, 2013; Marshall et al., 2011; Kremer et al., 2012).

In a study of carbonate concretions containing plant remains that have experienced high-pressure metamorphism,
Raman spectroscopy together with other methods was used to identify small-scale structural and chemical heterogeneities in megaspores despite blueschist facies (HP-LT) metamorphism (Bernard et al., 2007). In a Raman study of microfossils in cherts from the 700-800 Ma Draken Conglomerate, it was found that metastable opaline silica was preserved in the vicinity of the CM, which is surprising because opal-CT should not be stable in rocks of this age. Therefore it was proposed that the organic matter is stabilizing the opal-CT, and this association of opal and organic carbon can be considered as a biosignature (Foucher and Westall, 2013). FTIR spectroscopy has been used to study the chemical characteristics of CM in fossils. For example, an FTIR study of the Rhynie chert that contains exceptionally well-preserved plants, fungi, and arthropods confirmed that the organic functional groups inferred from the IR spectra correspond to GC-MS analysis of extracted organic compounds (Preston and Genge, 2010). Several studies have also applied a combination of Raman and FTIR spectroscopy to investigate Proterozoic acritarchs to decipher the phylogenetic affinities of fossilized palynomorphs that are morphologically similar but have different spectral characteristics (e.g., Marshall et al., 2005; Javaux and Marshall, 2006). To obtain spatially resolved chemical data, micro-FTIR can give a spot size of $c$. $20 \mu \mathrm{m}$ (see methods below), and when combined with Raman mapping together a spatial resolution of $0.5 \mu \mathrm{m}$ is achievable. It is therefore possible to distinguish fossilized subcellular features.

Here, a combination of Raman spectroscopy and microFTIR analysis was performed on fossils and CM from the Rhynie chert (410 Ma, Scotland), Bitter Springs Formation (820 Ma, Australia), and Wumishan Formation (1485 Ma, China). The reason for selecting the Rhynie chert and Bitter Springs Formation was because of the fossils and the fact that $\mathrm{CM}$ is exceptionally well preserved, with subcellular features impregnated by silica. In contrast, the Wumishan stromatolites contain organic carbon preserved in clots that lack cellular-grade preservation; these samples were included to test the application of this vibrational spectroscopy approach to less-well-preserved samples bearing candidate biosignatures. Below, we report the chemical and ultrastructural characteristics of the fossils and CM first to identify the influence of postdepositional processes and then to evaluate ultrastructural variations that arise from primary biological diversity and possibly subcellular differentiation within individual organisms. The overall aim is to develop an approach that can be applied to organic remains from the early rock record on Earth and potential biosignatures in Mars return samples.

\section{Basic Theory of Vibrational Spectroscopy Techniques}

The structural characteristic of CM in sedimentary and metamorphic rocks can be assessed by Raman spectroscopy (e.g., Wopenka and Pasteris, 1993; Yui et al., 1996; Beyssac et al., 2002, 2003; Jehlička et al., 2003; Rahl et al., 2005; Aoya et al., 2010; Bernard et al., 2010; Lahfid et al., 2010). At high metamorphic temperatures $\left(>650^{\circ} \mathrm{C}\right)$, the $\mathrm{CM}$ predominately consists of pure crystalline graphite with a Raman spectrum containing only a single G-band ( $\mathrm{G}$ for graphite) at $1580 \mathrm{~cm}^{-1}$ (Fig. 1a), due to E2g mode vibration of sp2-bonded 
FIG. 1. Examples of Raman spectra in the range of $1000-1800 \mathrm{~cm}^{-1}$ of carbonaceous material (CM) with different structural order. (a) The Raman spectrum of well-graphitized $\mathrm{CM}$ at high metamorphic temperature with a narrow G-band at $1580 \mathrm{~cm}^{-1}$. (b) The Raman spectrum of CM at medium metamorphic temperatures has additional bands, D1 at $1350 \mathrm{~cm}^{-1}$, D2 at $1620 \mathrm{~cm}^{-1}$, sometimes with small D3- and D4-bands. (c) At low metamorphic temperature or advanced diagenesis, the poorly ordered CM has D1-band, D2-, D3-, D4-, and sometimes D5-bands.

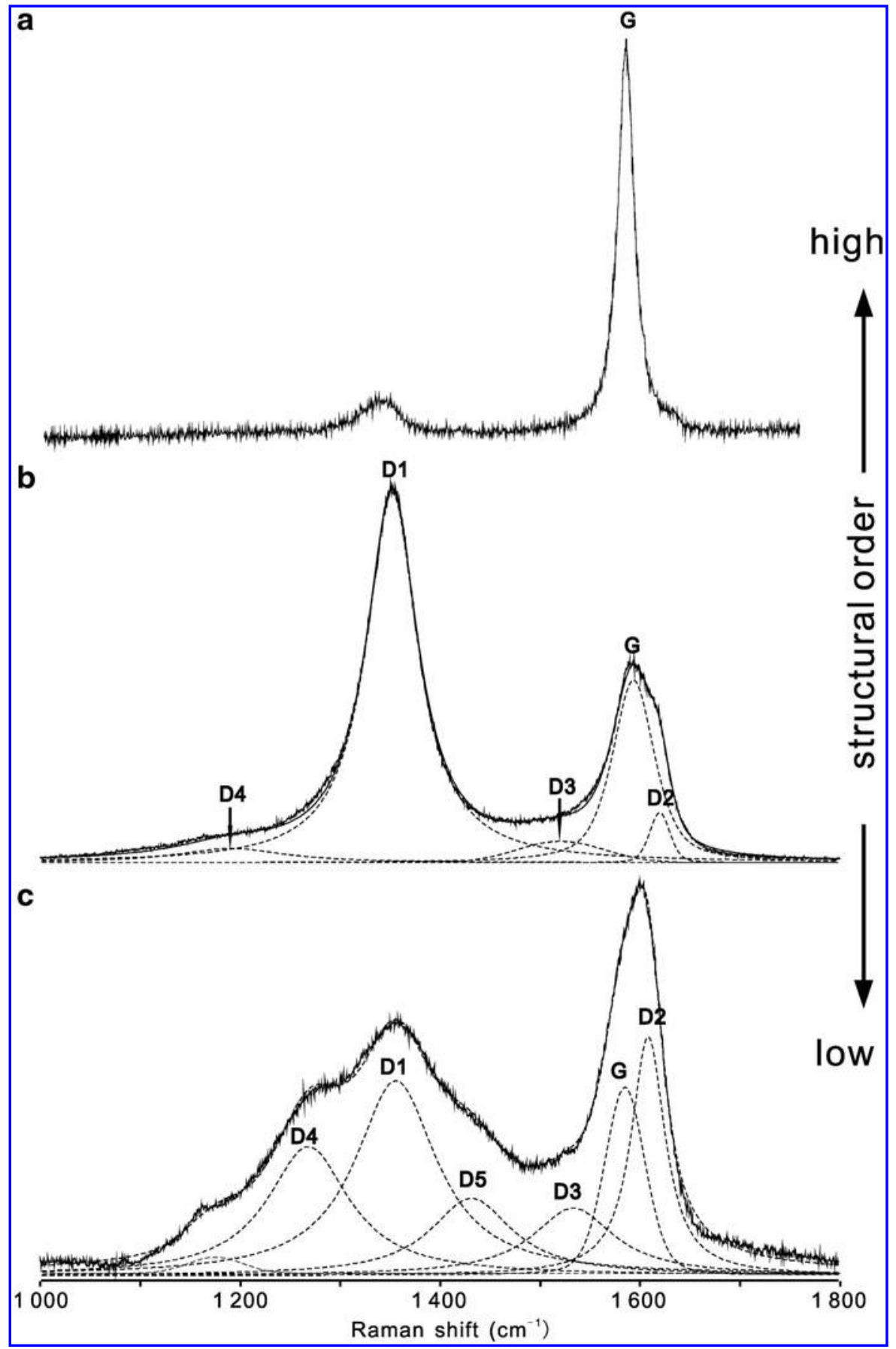

hexagonal ring structures (Tuinstra and Koenig, 1970). At lower metamorphic temperatures (approximately from $320^{\circ} \mathrm{C}$ to $650^{\circ} \mathrm{C}$ ), the defects or heteroatoms in relatively disordered $\mathrm{CM}$ restrict the in-plane domain size of graphene layers and cause $\mathrm{A}_{1 \mathrm{~g}}$ breathing mode vibration of $\mathrm{sp}^{2}$ rings, inducing the $\mathrm{D} 1$-band (D for disorder) at $1350 \mathrm{~cm}^{-1}$ and $\mathrm{D} 2$-band at $1620 \mathrm{~cm}^{-1}$ (Fig. 1b, Tuinstra and Koenig, 1970; Beyssac et al., 2002). Under advanced diagenesis at even lower temperatures $\left(<320^{\circ} \mathrm{C}\right)$, the composition and structure of $\mathrm{CM}$ is more complex, including out-of-plane defects associated with heteroatoms, dangling bonds and tetrahedral coordinated carbons, and aromatic substances; therefore, the D1-band splits into
D3-, D4-, and sometimes D5-band at around 1510, 1245, and $1460 \mathrm{~cm}^{-1}$, respectively (Fig. 1c, Sadezky et al., 2005; Lahfid et al., 2010; Kouketsu et al., 2014; Romero-Sarmiento et al., 2014; Sforna et al., 2014a).

Several parameters derived from the first order of Raman spectra in the range of $150-2000 \mathrm{~cm}^{-1}$ can describe the structural order of CM, some of which are used as geothermometers to estimate the peak metamorphic temperatures (e.g., Tuinstra and Koenig, 1970; Beyssac et al., 2002; Rahl et al., 2005; Lahfid et al., 2010; Kouketsu et al., 2014). The definitions and valid temperature ranges for these parameters are briefly summarized below: 
(1) $\mathrm{I}-\mathrm{D} / \mathrm{G}=$ intensity ratio of band at $1350 / 1580 \mathrm{~cm}^{-1}$ (Tuinstra and Koenig, 1970; Bonal et al., 2006)

(2) $\mathrm{R} 1=$ intensity ratio of $\mathrm{D} 1 / \mathrm{G}$; or $\mathrm{R} 2=$ area ratio of $\mathrm{D} 1 /$ $(\mathrm{G}+\mathrm{D} 1+\mathrm{D} 2)$ with temperature dependence given by

$T=-445 \times \mathrm{R} 2+641$, suitable in the range $330-700^{\circ} \mathrm{C}$ (Beyssac et al., 2002)

$T=737.3+320.9 \times \mathrm{R} 1-1067 \times \mathrm{R} 2-80.638 \times \mathrm{R} 1^{2}$, suitable in the range $100-700^{\circ} \mathrm{C}(\mathrm{Rahl}$ et al., 2005)

(3) $\mathrm{RA} 1=$ area ratio of $(\mathrm{D} 1+\mathrm{D} 4) /(\mathrm{D} 1+\mathrm{D} 2+\mathrm{D} 3+\mathrm{D} 4+\mathrm{G})$; $\mathrm{RA} 2=$ area ratio of $(\mathrm{D} 1+\mathrm{D} 4) /(\mathrm{D} 2+\mathrm{D} 3+\mathrm{G})$ with a temperature dependence given by

$T=(\mathrm{RA} 1-0.3758) / 0.0008 ; T=(\mathrm{RA} 2-0.27) / 0.0045$, suitable in the range $200-320^{\circ} \mathrm{C}$ (Lahfid et al., 2010)

(4) FWHM-D1 and FWHM-D2 = full width at half maximum of D1-, and D2-band, with a temperature dependence given by

$T=-2.15 \times($ FWHM-D1 $)+478 ; T=-6.78 \times($ FWHM-

D2) +535 , suitable in the range $165-655^{\circ} \mathrm{C}$

(Kouketsu et al., 2014).

Fourier transform infrared spectroscopy can be used to investigate functional groups of $\mathrm{CM}$ in fossils and sedimentary rocks (e.g., Marshall et al., 2005; Igisu et al., 2006, 2009, 2014; Lepot et al., 2009). Different functional groups in organic molecules give rise to specific peaks in the IR spectra due to various stretching and/or bending vibrations of bonds in aliphatic $\mathrm{C}-\mathrm{H}$ of $\mathrm{CH}_{3} / \mathrm{CH}_{2}, \mathrm{C}-\mathrm{N}, \mathrm{C}=\mathrm{O}, \mathrm{C}-\mathrm{O}$, and aromatic $\mathrm{C}=\mathrm{C}$. The absorbance ratio of asymmetric stretching band of aliphatic $\mathrm{CH}_{3}$ end-methyl versus $\mathrm{CH}_{2}$ chain-methylene, defined as $R_{3 / 2}=$ intensity ratio of $2960 \mathrm{~cm}^{-1}$-band $/ 2925 \mathrm{~cm}^{-1}$-band, is usually used to describe the branching index of carbon chains (Igisu et al., 2009). It has been proposed that CM derived from different domains of life, for example, eukaryotes, prokaryotes, and archaea, have their own $R_{3 / 2}$ ranges due to different lipid compounds in their cellular structures (Igisu et al., 2009). In this study, we tested to discern whether the $R_{3 / 2}$ and Raman spectral parameters vary between fossilized eukaryotic and prokaryotic organisms.

\section{Geological Setting and Sample Material}

The Early Devonian Rhynie chert in northeastern Scotland occurs within the "old red sandstone" succession consisting of primarily sandstones, shales, and subordinate volcanic rocks. The chert units are siliceous sinter, formed when Si-rich fluids from hot springs migrated and flooded the fluvial and lacustrine sediments (Trewin, 1993; Rice et al., 1995, 2002). The Rhynie chert is well known for recording the earliest reported Devonian subaerial, terrestrial, and freshwater ecosystems and for the exceptionally well-preserved and diverse communities including plants (Kidston and Lang, 1920a, 1920b), animals (Whalley and Jarzembowski, 1981; Fayers and Trewin, 2002), algae (Edwards and Lyon, 1983), fungi (Remy et al., 1994a, 1994b; Taylor et al., 2004), lichen (Taylor et al., 1997), and cyanobacteria (Croft and George, 1959; Taylor et al., 1997). The depositional age of the chert is estimated to be $396 \pm 12 \mathrm{Ma}\left({ }^{40} \mathrm{Ar} /{ }^{39} \mathrm{Ar}\right.$, Rice et al., 1995), and the Lower Devonian Rhynie Outlier is constrained to be $411.5 \pm 1.3 \mathrm{Ma}$
(U-Pb zircon, Parry et al., 2011), which was also confirmed by the biostratigraphy of fossilized spores in muddy sediments associated with the Rhynie chert (estimated to 410$400 \mathrm{Ma}$, Wellman, 2004).

The Bitter Springs Formation is located in the Amadeus Basin of central Australia, consisting of predominately carbonates; siltstones; evaporites; and frequent lenses, nodules, and thin beds of cherts (Wells et al., 1970). The Bitter Springs Formation was deposited in a restricted basin or lagoon on a marginal platform. In the upper part of the Bitter Springs Formation, deposited in a shallow marine setting, microbial films and stromatolitic bioherms are common. These were preserved during the rapid silicification throughout the basin, possibly due to Si-rich fluids from contemporary volcanisms (Wells et al., 1970). Microbial communities of coccoidal and filamentous cyanobacteria are well preserved in the cherts of Bitter Springs Formation (Schopf, 1968; Schopf and Blacic, 1971; Knoll and Golubic, 1979). The age of the Bitter Springs Formation based on U-Pb dating of baddelyite is constrained to be $824 \pm 4 \mathrm{Ma}$ (Glikson et al., 1996; Edgoose, 2012).

The Wumishan Formation in Jixian, northern China, comprises a $3300 \mathrm{~m}$ thick stromatolitic carbonate succession (Mei et al., 2008). The succession contains numerous meterscale cyclothems of peritidal carbonates consisting of subtidal stromatolitic biostromes, thrombolitic bioherms, tidal-flat micritic dolomites, lagoon facies dolomitic mudstone, and shale (Mei et al., 2001a, 2001b, 2008). There are abundant stromatolites in Wumishan Formation, including microdigitate columnar stromatolites (Liang et al., 1984, 1985; Zhou et al., 1989; Zhu et al., 1993, 1994; Mei et al., 2008). Examples of well-preserved cyanobacterial microfossils including Eomycetopsis, Animikiea, and Rhicnonema have been found in these stromatolites (Liang et al., 1984). The age of Wumishan Formation is constrained between $1483 \pm 13 \mathrm{Ma}$ and $1487 \pm 16 \mathrm{Ma}$ (Li et al., 2014).

For this study, four polished thin sections were chosen. In one thin section from the Rhynie chert (RYC 2b 3 loaned from Prof. M.D. Brasier, University of Oxford), we targeted areas containing fungi, identified as Chytridiomycetes ( $c f$. 1-7 in Remy et al., 1994a), also plant material including stem components from Rhynia (cf. 1 in Satterthwait and Schopf, 1972) and Aglaophyton (cf. 2 and 20 in Edwards, 1986). In the Bitter Springs samples, two thin sectionsTBS-22-1-B and TBS-22-1-C, published in Knoll and Golubic (1979) and loaned from Prof. A.H. Knoll, Harvard University-we focused on coccoidal microfossils (Gloeodiniopsis lamellosa Schopf em., Fig. 7B in Knoll and Golubic, 1979) and filamentous microfossils (Cephalophytarion, Plate 105 and 106 in Schopf and Blacic, 1971). In one thin section from the Wumishan Formation (sampled by the authors in the field), we targeted the CM within lamina of silicified stromatolite of Pseudogymnosolen (Plate I and II in Liang et al., 1984; Fig. 3 in Liang et al., 1985; and Fig. 3 in Mei et al., 2008) hosted in chert and calcite. The samples and their geological background information are summarized in Table 1.

\section{Methods}

The petrographic and Raman spectroscopic analyses were performed on polished thin sections of $c .30 \mu \mathrm{m}$ thickness using a Nikon Eclipse LV100POL polarizing optical microscope in transmission mode and a Horiba-Jobin Labram 
Table 1. Generalized Geological Background of Material Studied in This Research

\begin{tabular}{lllll}
\hline Site & Age & Lithology & Depositional setting & \multicolumn{1}{c}{ Fossils } \\
\hline Rhynie chert & $410 \mathrm{Ma}$ & chert & terrestrial & plants, fungi \\
Bitter Springs & $820 \mathrm{Ma}$ & chert & shallow marine & cyanobacteria \\
Wumishan & $1485 \mathrm{Ma}$ & chert and calcite & intertidal-subtidal zone & stromatolite \\
\hline
\end{tabular}

800 HR Raman spectrometer linked to an Olympus BX41 petrographic microscope at the Centre for Geobiology, University of Bergen, Norway. The Raman spectra were acquired with a $514 \mathrm{~nm}$ Ar-ion laser with absolute laser power of $15-20 \mathrm{~mW}$ through a density filter $(D=0.3), 100 \times$ objective and aperture hole $=100 \mu \mathrm{m}$ with the final power of c. $2.5 \mathrm{~mW}$ (measured with a Coherent Lasercheck Analyser) in a $c .1-2 \mu \mathrm{m}$ spot on the sample. The laser beam was focused on the CM underneath the polished surface of thin sections to avoid surface contamination and polishing artifacts (Pasteris, 1989; Beyssac et al., 2003; Ammar and Rouzaud, 2012; Maslova et al., 2012). The Raman spectra were obtained in multiwindow mode with $2 \times 10 \mathrm{~s}$ integration time and a spectral range of $150-2000 \mathrm{~cm}^{-1}$, and treated with software Lab Spec version 5.58.25. According to Kouketsu et al. (2014), spectra were subtracted by a linear baseline from 1000 to $1750 \mathrm{~cm}^{-1}$ to remove the background fluorescence. According to the method for CM-experienced low-grade metamorphism (Kouketsu et al., 2014), the peak fitting and characterization were performed by peak deconvolution using a Gauss-Lorentzian function with 100 iterations per fit.

The micro-FTIR analysis was performed on doubly polished rock wafers using an IR microscope coupled to an IR spectrometer in transmission mode at Beamline D7 in the MAX III ring of Maxlab in Lund, Sweden. The FTIR equipment consists of a Bruker IFS66V FTIR spectrometer, a Bruker Hyperion 3000 microscope with a $15 \times$ IR objective, and a $100 \times 100$ micron MCT detector for the mid-IR region. An aperture was used to focus on the target fossils and CM, with measured spots down to $15 \times 15 \mu \mathrm{m}^{2}$. The rock wafer samples were put on a $\mathrm{CaF}_{2}$ window, and IR spectra were measured. A reference background IR spectrum was measured on the $\mathrm{CaF}_{2}$ window before the measurement of every sample. The spectra were acquired from wavenumbers 500 to $7500 \mathrm{~cm}^{-1}$ by the integration of 256 scans and were represented as IR absorbance in this range. The IR spectra were processed and calculated with the software Lab Spec version 5.58.25.

\section{Results}

\subsection{Raman spectral characteristics of carbonaceous material}

All the measured Raman spectra of CM within the Rhynie chert, Bitter Springs, and Wumishan samples record two broad peaks at around 1350 and $1600 \mathrm{~cm}^{-1}$ typical of disordered carbon, with another peak occurring at $465 \mathrm{~cm}^{-1}$ indicating the coexisting quartz matrix (Fig. 2a). Decomposing the spectra, the broad band at $1350 \mathrm{~cm}^{-1}$ actually consists of three subpeaks: D4- (at $1270 \mathrm{~cm}^{-1}$ ), D1- (at $1350 \mathrm{~cm}^{-1}$ ), and D5- (at $1430 \mathrm{~cm}^{-1}$ ) bands; and the $1600 \mathrm{~cm}^{-1}$ peak is composed of G(at $1580 \mathrm{~cm}^{-1}$ ) and D2- (at $1620 \mathrm{~cm}^{-1}$ ) bands (Fig. 2b). In addition, there is another band between the 1350 and $1600 \mathrm{~cm}^{-1}$ peaks defined as the D3-band at approximately $1500 \mathrm{~cm}^{-1}$ (Fig. 2b). In this study, the Raman spectra decomposition and peak calculations were performed in two ways: (1) by only taking the main bands at 1350 and $1600 \mathrm{~cm}^{-1}$ into account, and the intensity ratio of $1350 \mathrm{~cm}^{-1}$-band versus $1600 \mathrm{~cm}^{-1}$-band is defined as I-1350/1600 (Fig. 2a); (2) by decomposing the spectra range from 1000 to $1800 \mathrm{~cm}^{-1}$ into D4-, D1-, D5-, D3-, G-, and D2bands and calculating the associated parameters (Fig. 2b).

The Raman spectra obtained from various CM in the Rhynie chert show systematic differences with certain morphological features probably indicate different cellular components. In the plant stem, the cell walls have a higher ratio of $1350 \mathrm{~cm}^{-1}$-band versus $1600 \mathrm{~cm}^{-1}$-band (defined as
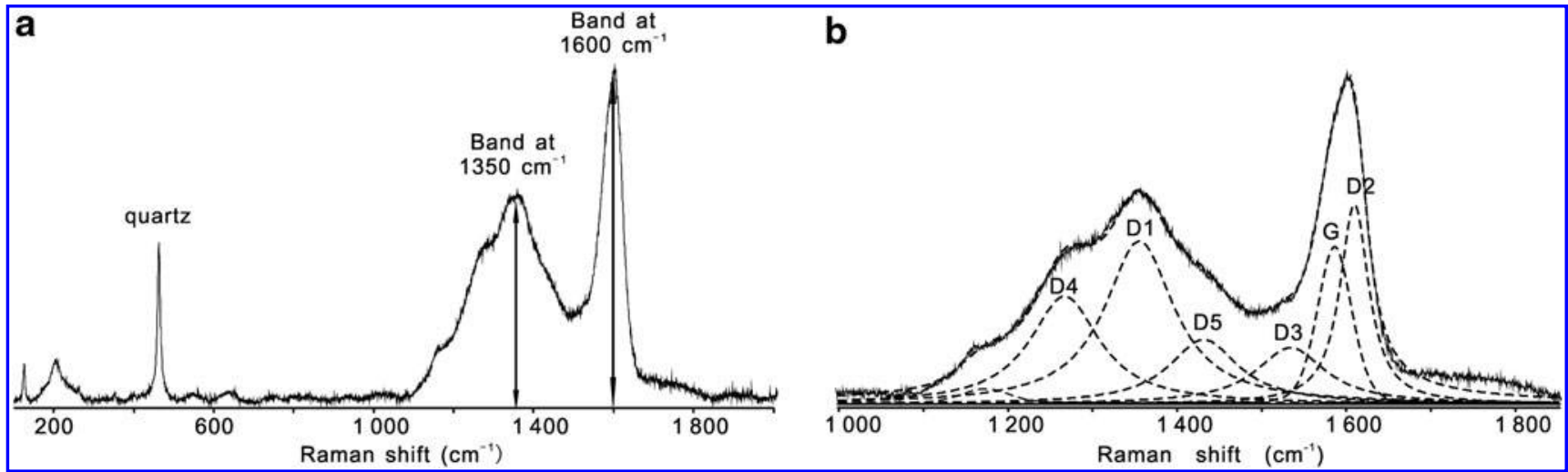

FIG. 2. A representative Raman spectrum of CM from the Rhynie chert illustrating two different ways of decomposing the spectrum used in this study. (a) The Raman spectrum from 100 to $2000 \mathrm{~cm}^{-1}$ that in addition to the quartz band at $465 \mathrm{~cm}^{-1}$ has two CM bands at 1350 and $1600 \mathrm{~cm}^{-1}$ that are used to calculate the intensity ratio between them defined as $I-$ 1350/1600. (b) Zoom-in of (a) showing the Raman spectrum between 1000 and $1800 \mathrm{~cm}^{-1}$ decomposed into D1-, D2-, D3-, D4-, D5-, and G-bands. (Further explanation in Section 5.1 of the text.) 
I-1350/1600) of Raman spectra than those of the protoplasm (Figs. 3a-3c). The spectral parameters have been calculated and plotted in Supplementary Fig. S1 (Supplementary Data available online at www.liebertonline.com/ast), where the cell walls of the plant have systematically higher I-1350/ 1600 and lower FWHM-D2 than their protoplasm. The epidermis and cell walls of the sclerenchyma have similar spectra (Figs. 3d-3f) and ranges of $I-1350 / 1600$ and FWHM-D2, respectively (Supplementary Fig. S1). However, the black formless CM filling between the cells (Figs. $3 \mathrm{~d}, 3 \mathrm{e})$, which is probably derived from extracellular phloem sap, has higher I-1350/1600 and lower FWHM-D2 than the epidermis and cell walls of sclerenchyma (Fig. 3f, Supplementary Fig. S1). The Raman spectra acquired from fungal tufts, rhizoid, and the cell walls of rhizoidbearing plant stem also show differing $I-1350 / 1600$ values (Figs. 3g-3i). The fungal tufts have higher $I-1350 / 1600$ and lower FWHM-D2 values of Raman spectra compared to those from the fungi-bearing plant stem, whereas the fungal rhizoid penetrating into the epidermis has $I-1350 / 1600$ and FWHM-D2 values that are between their tufts and the host plant stem (Figs. 3g-3i, Supplementary Fig. S1).
In the Bitter Springs samples, the Raman spectra and the associated parameters of the different types of $\mathrm{CM}$ investigated - coccoidal microfossils (Figs. 4a, 4b), filamentous microfossils (Figs. 4d, 4e), laminated (Fig. 4g), and clotted (Fig. 4h) CM-show some variation (Figs. 4c, 4f, 4i). However, the whole data set of Raman spectral parameters does not record systematic variation between these different morphological types of CM (Supplementary Fig. S2). The CM within Wumishan stromatolite is not morphologically diverse but occurs predominantly as aggregates in the dark lamina (Fig. 5b), probably derived from cyanobacteria. Unfortunately, there is no cellular structure preserved due to decomposition of the organic matter. The Raman spectral parameters are plotted in Supplementary Fig. S3.

The systematic variation in the Raman properties of the different morphological components was further investigated by two-dimensional Raman mapping (Figs. 6 and 7). The intensities of $1350 \mathrm{~cm}^{-1}$-band (Figs. 6b, 6f, 6j, 7b, 7f) and $1600 \mathrm{~cm}^{-1}$-band (Figs. 6c, 6g, 6k, 7c, 7g) were mapped and indicate the relative abundance of organic carbon of different ultrastructures within various biological tissues and subcellular components. Most of the Raman spectra in the maps
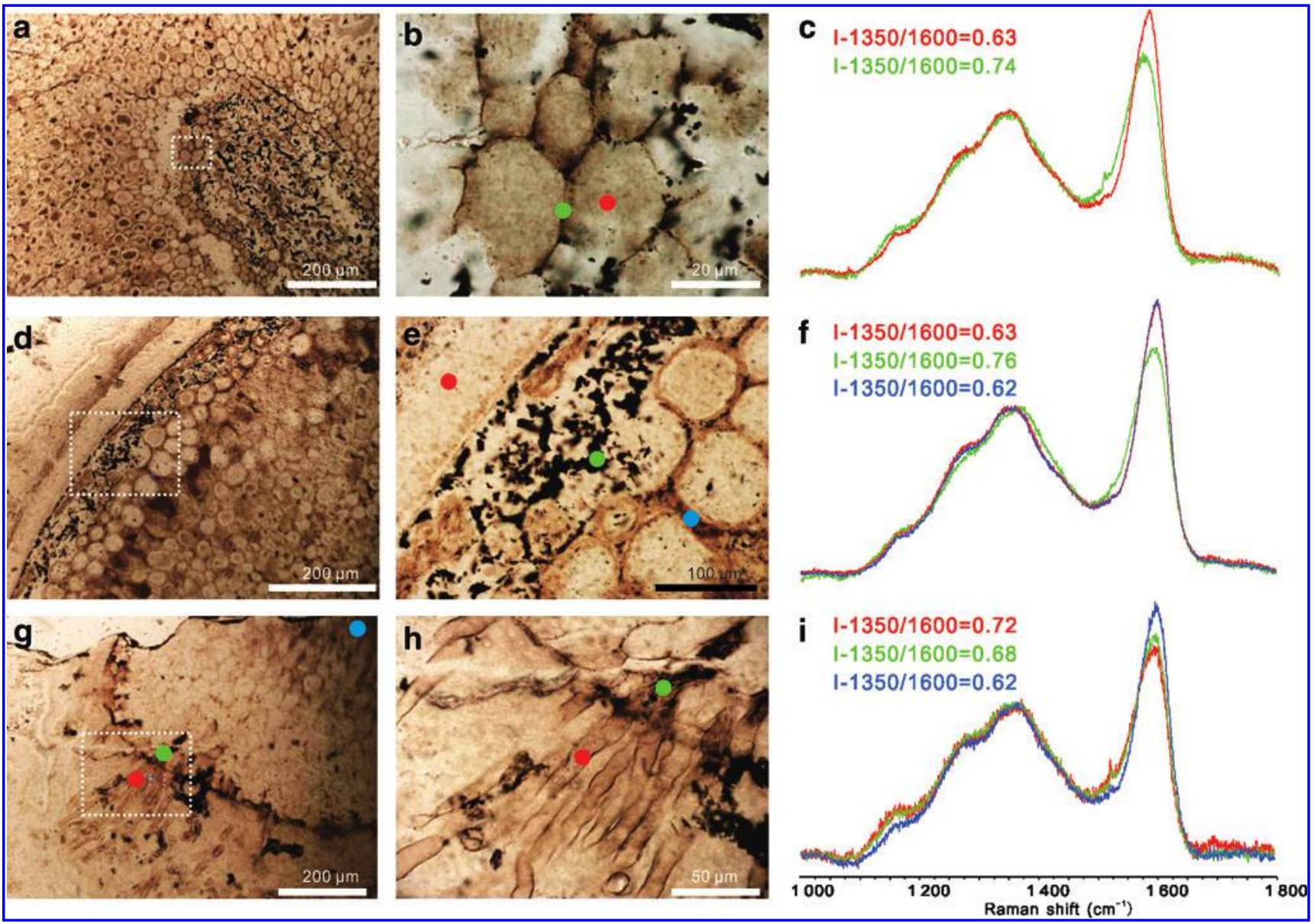

FIG. 3. Optical microscopic images of selected fossils and CM with their corresponding Raman spectra from the $410 \mathrm{Ma}$ Rhynie chert; the colored spots show the location of the Raman analysis, with the spectra and calculated parameter I-1350/ 1600 shown on the right in the corresponding colors. $(\mathbf{a}-\mathbf{c})$ The pith of a plant stem showing preserved cellular structures that are brownish in color. (d-f) The extracellular black formless CM between the cell walls of phloem and epidermis. (g-i) Cross section through an epilithic filamentous fungi growing outward from the host plant stem. Sample number RYC $2 \mathrm{~b} 3$. (Color graphics available at www.liebertonline.com/ast) 

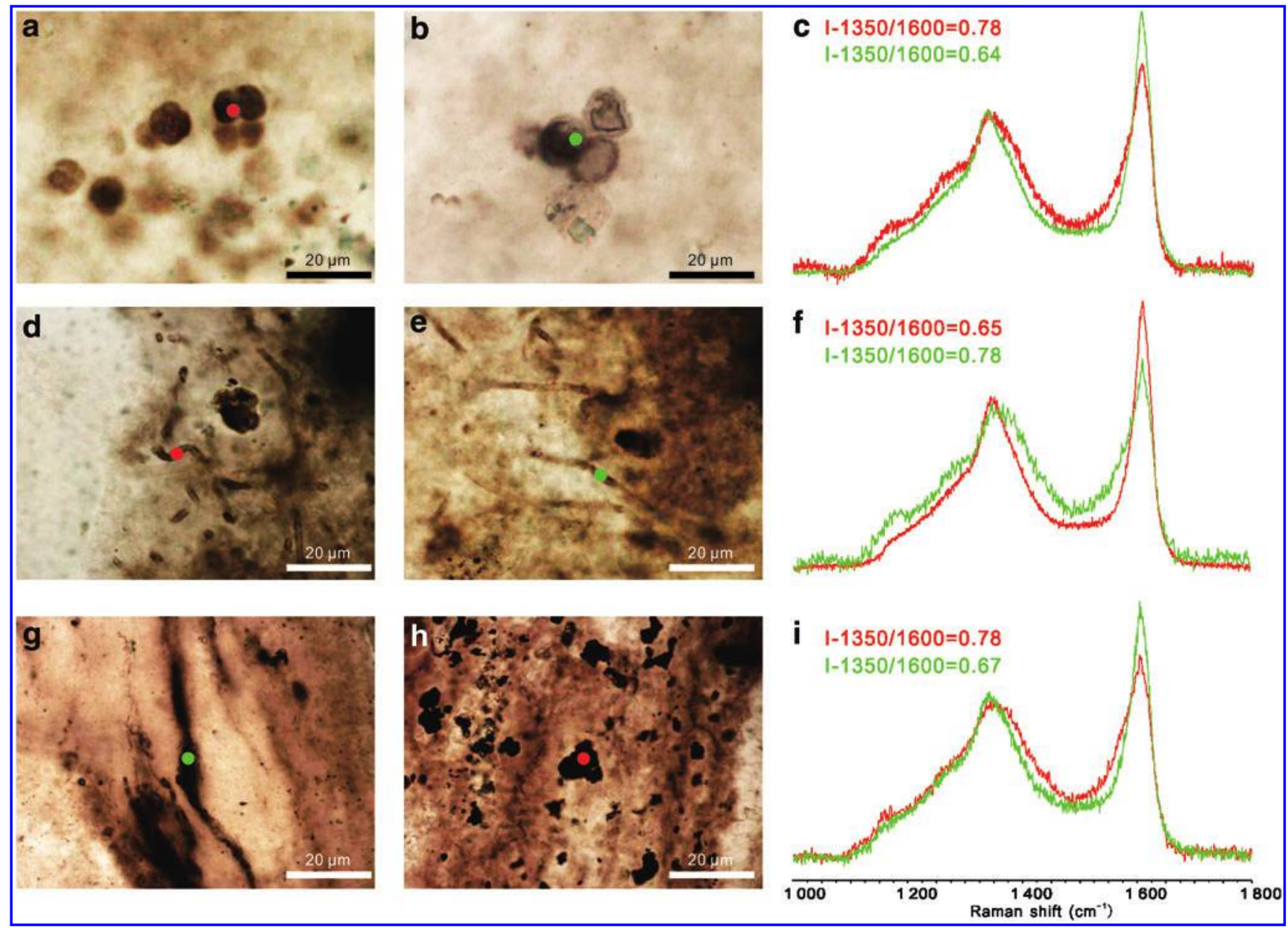

FIG. 4. Optical microscopic images of selected fossils and CM and their corresponding Raman spectra from Bitter Springs samples; the colored spots show the locations of the Raman analysis, with the spectra and calculated parameter I-1350/1600 shown on the right. (a-c) Clusters of coccoidal cyanobacteria. (d-f) Filamentous cyanobacteria. (g-i) Laminated and clotted black CM. Samples are from TBS-22-1-B and TBS-22-1-C in Knoll and Golubic (1979). (Color graphics available at www.liebertonline.com/ast)

have high intensities of $1350 \mathrm{~cm}^{-1}$ - and $1600 \mathrm{~cm}^{-1}$-bands, whereas some mineral matrix has low intensities of these two bands due to low concentration of CM (the black color in Figs. 6j, 6k). To avoid significant error, the spectra with the intensities of $1350 \mathrm{~cm}^{-1}$ - and $1600 \mathrm{~cm}^{-1}$-bands that are lower than $c .5 \%$ of the maximum intensities of these two bands in the map were filtered in the maps of $I-1350 / 1600$. The Raman maps show that the cell walls of plant stems have systematically higher $I-1350 / 1600$ ratios than their protoplasm (Fig. 6d). The black formless extracellular CM has higher $I-1350 /$

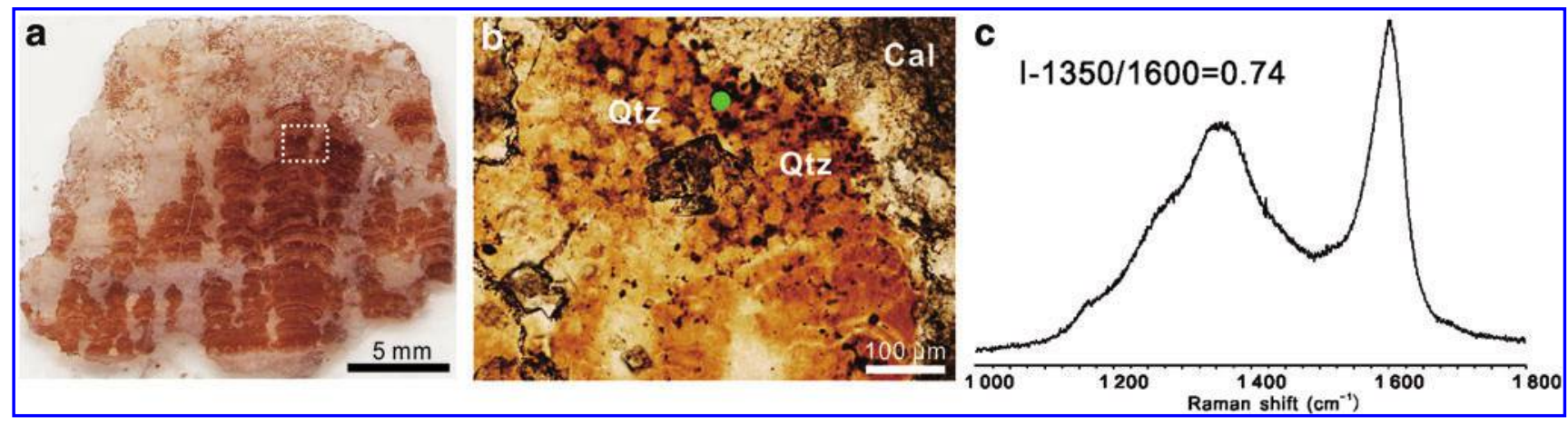

FIG. 5. Optical microscopic images and Raman spectrum of $\mathrm{CM}$ in microdigitate stromatolite from the Wumishan Formation. (a) Polished thin section image showing silicified microdigitate stromatolites with carbonate matrix in the upper part. (b) The enlarged optical microscopic image of the white dashed box in (a) showing location of dark CM within the stromatolite laminae comprising quartz (Qtz) and calcite $(\mathrm{Cal})$. (c) The Raman spectrum and parameter I-1350/1600 of CM measured on the green spot in (b). (Color graphics available at www.liebertonline.com/ast) 


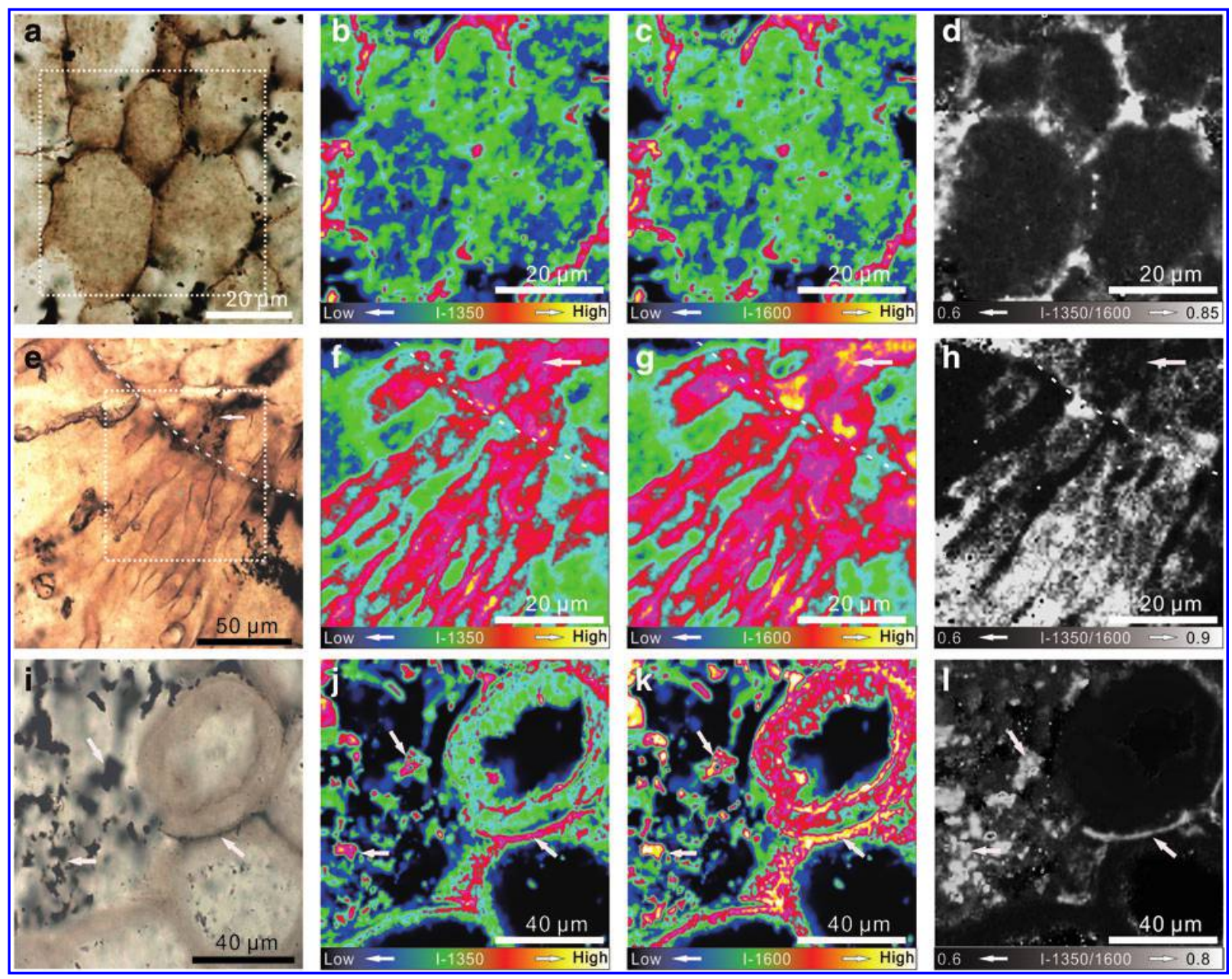

FIG. 6. Optical microscopic images and two-dimensional Raman maps of fossils and CM from the Rhynie chert. (a) The optical microscopic image of the cell ultrastructure within the plant stem; the white dashed box shows areas corresponding to Raman maps to the right. (b-c) The Raman maps of the relative intensity of $1350 \mathrm{~cm}^{-1}-\mathrm{band}(I-1350)$ and $1600 \mathrm{~cm}-1$ band (I-1600), respectively, indicating the $\mathrm{C}$ concentration in the cellular structures. (d) The Raman maps of relative intensity ratio of $1350 \mathrm{~cm}^{-1} / 1600 \mathrm{~cm}^{-1}$-band (defined as $I-1350 / 1600$ ), indicating higher structural order of CM within cell walls than the protoplasm. (e) The optical microscopic image of epilithic filamentous fungi growing outward from the host plant stem. The arrow indicates the fungal rhizoid penetrated into the stem, the dashed line represents the epidermis of the plant stem, and the white dashed box shows areas corresponding to Raman maps to the right. (f-g) The Raman maps of $I$ 1350 and $I-1600$, respectively. (h) The Raman maps of $I-1350 / 1600$, showing higher structural order of CM within fungi than that in the host plant. (i) The optical microscopic image of extracellular black formless CM (arrowed) between the cell walls of a plant stem. (j-k) the Raman maps of $I-1350$ and $I-1600$, respectively, indicating high concentrations of carbon in the cell walls and the extracellular formless CM. (I) The Raman maps of $I-1350 / 1600$, showing higher structural order of the extracellular CM than the adjacent cell walls. The color scales increase from blue, green, red to yellow (in b, c, f, g, j, k) or from black to white (in $\mathrm{d}, \mathrm{h}, \mathrm{l}$ ). (Color graphics available at www.liebertonline.com/ast)

1600 values than the adjacent cell walls in the phloem (Fig. $61)$. The fungi tufts have higher $I-1350 / 1600$ values than their rhizoids and the epidermis of host plant stem (Fig. 6h).

In the Bitter Springs samples, the subcellular structure of fossilized coccoidal cyanobacteria is revealed in the Raman maps (Figs. 7b, 7c, 7f, 7g). The coccoidal microfossil is apparently in a divisional phase ( $c f .9$ in Knoll and Golubic, 1979), as illustrated by the abundance of organic carbon recorded by the relative intensities of the $1350 \mathrm{~cm}^{-1}$ - and $1600 \mathrm{~cm}^{-1}$-bands in Figs. 7b, 7c. The cellular-scale spatial distribution of $\mathrm{CM}$ within the filamentous fossils is shown by the relative intensities of $1350 \mathrm{~cm}^{-1}$ - and $1600 \mathrm{~cm}^{-1}$ bands in Figs. $7 \mathrm{f}, 7 \mathrm{~g}$. However, the $I-1350 / 1600$, indicating the structural order of CM, in both the coccoidal and filamentous fossils does not change according to the cellular morphology (Figs. 7d, 7h).

\subsection{Micro-FTIR}

The IR absorbance spectra of selected fossils and CM in the Rhynie chert and Wumishan stromatolites were obtained in transmission mode. The spectral bands with relatively high peak intensity between 2800 and $3000 \mathrm{~cm}^{-1}$, which indicate strong IR absorbance of $\mathrm{CH}_{2}$ and $\mathrm{CH}_{3}$, are presented in Fig. 8. All the spectra contain seven bands at 1995, 1870, 1793, 1684, 1610, 1525, and $1492 \mathrm{~cm}^{-1}$ (Fig. 8e) 


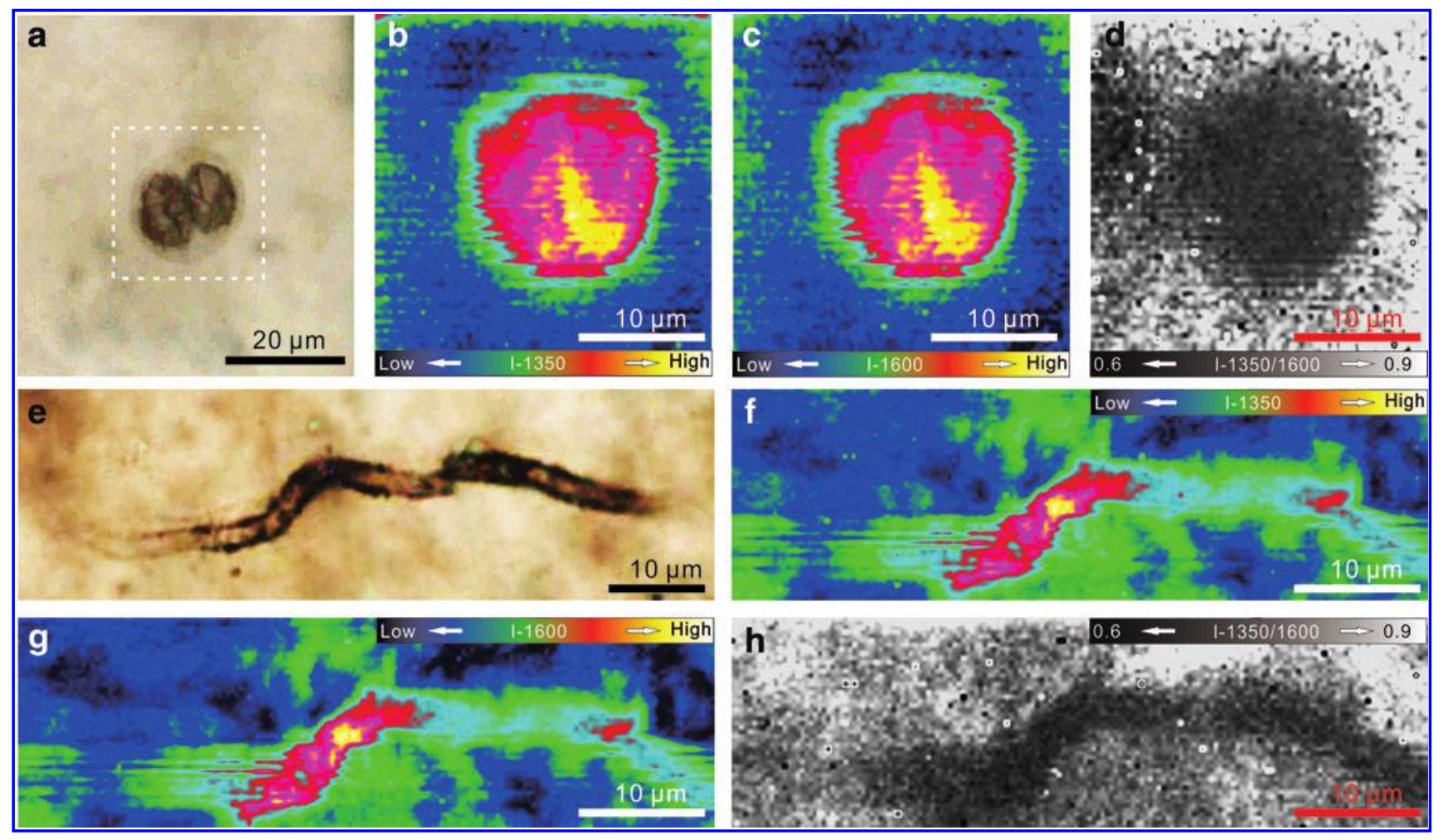

FIG. 7. Optical microscopic images and two-dimensional Raman maps of microfossils and CM from the Bitter Springs Formation. (a) The optical image of a coccoidal microfossil in apparent cell division phase, splitting along a central linear zone. (b-c) The Raman maps of $I-1350$ and $I-1600$, respectively, with the cell wall and central linear zone clearly visible. (d) Raman map of $I-1350 / 1600$ shows the cell in mineral matrix but without obvious internal structural variation. (e) The optical image of a filamentous microfossil. $(\mathbf{f}-\mathbf{g})$ The Raman map of $I-1350$ and $I$-1600, respectively, shows some internal variation within the filament. (h) The Raman maps of $I-1350 / 1600$ show no obvious variation within the filamentous microfossil. The color scales increase from blue, green, red to yellow (in b, c, f, g) or from black to white (in d, h). (Color graphics available at www.liebertonline.com/ast)

derived from the overtones and combinations of Si-O vibrations of quartz (Ito and Nakashima, 2002) in the siliceous mineral matrix. A broad band at around $3400 \mathrm{~cm}^{-1}$ represents $\mathrm{O}-\mathrm{H}$ stretching vibration of molecular $\mathrm{H}_{2} \mathrm{O}$ (Aines and Rossman, 1984), most likely from the chert. In the range of $2800-3000 \mathrm{~cm}^{-1}$, there are three bands at 2850,2925 , and $2960 \mathrm{~cm}^{-1}$, indicating the symmetric stretching vibration of $\mathrm{C}-\mathrm{H}$ bond in $\mathrm{CH}_{2}$, the asymmetric stretching vibration of $\mathrm{C}-\mathrm{H}$ bond in $\mathrm{CH}_{2}$ and $\mathrm{CH}_{3}$, respectively (Bellamy, 1954, Fig. 8f).

In the Rhynie chert, the whole data set of $R_{3 / 2}$ values, defined as the intensity ratio of $2960 \mathrm{~cm}^{-1}$-band $/ 2925 \mathrm{~cm}^{-1}$ band, are in the range from 0.19 to 0.61 , and in each type of fossil and $\mathrm{CM}$ the $R_{3 / 2}$ shows some variations (Supplementary Fig. S4). The $R_{3 / 2}$ of the protoplasm of the plant stem ranges from 0.19 to 0.45 (averagely 0.36 ) and is lower than that of the surrounding cell walls $\left(R_{3 / 2}=0.5-0.61\right.$, average $=0.56$, Fig. 8f, Supplementary Fig. S4). The epidermis of the plant stem has an averagely lower $R_{3 / 2}$ value $\left(R_{3 / 2}\right.$ $=0.4-0.51$, average $=0.47$ ) than the adjacent cell walls (Fig. 8f, Supplementary Fig. S4). The $R_{3 / 2}$ of the black formless extracellular CM shows a wide range from 0.27 to 0.59 with an average of 0.43 (Fig. 8f, Supplementary Fig. S4). In Wumishan stromatolite, the $R_{3 / 2}$ of $\mathrm{CM}$ aggregates ranges from 0.17 to 0.25 , with an average of 0.21 (Supplementary Fig. S4).
Due to lack of material for making doubly polished thin sections, the micro-FTIR analysis has not been performed on the Bitter Springs samples in this study. However, the $R_{3 / 2}$ values of coccoidal $(=0.32)$ and filamentous $(=0.33) \mathrm{mi}-$ crofossils in the Bitter Springs Formation have been reported by Igisu et al. (2006, 2009), which will be discussed in the following paragraphs.

\section{Discussion}

\subsection{Selection of appropriate Raman spectral parameters for assessing the structural order of low-grade carbonaceous material}

In this study, all the Raman spectra contain a broad band at $1350 \mathrm{~cm}^{-1}$ consisting of D4-, D1-, D5-, and D3-bands in the fossils and CM (Figs. 2, 3, 4, and 5), which is typical for CM that has experienced advanced diagenesis or low-grade metamorphism (Kouketsu et al., 2014). There are several different methods for calculating the metamorphic temperatures (see Section 2), and these estimates will now be compared and discussed to select the most appropriate to our samples. The FWHM-D1- and FWHM-D2-based calculations indicate that $\mathrm{CM}$ from the Rhynie chert, Bitter Springs, and Wumishan stromatolite samples experienced peak metamorphic temperatures estimated at $255-345^{\circ} \mathrm{C}, 235-340^{\circ} \mathrm{C}$, and $250-320^{\circ} \mathrm{C}$, respectively (Supplementary Figs. S1-S3). An alternative 

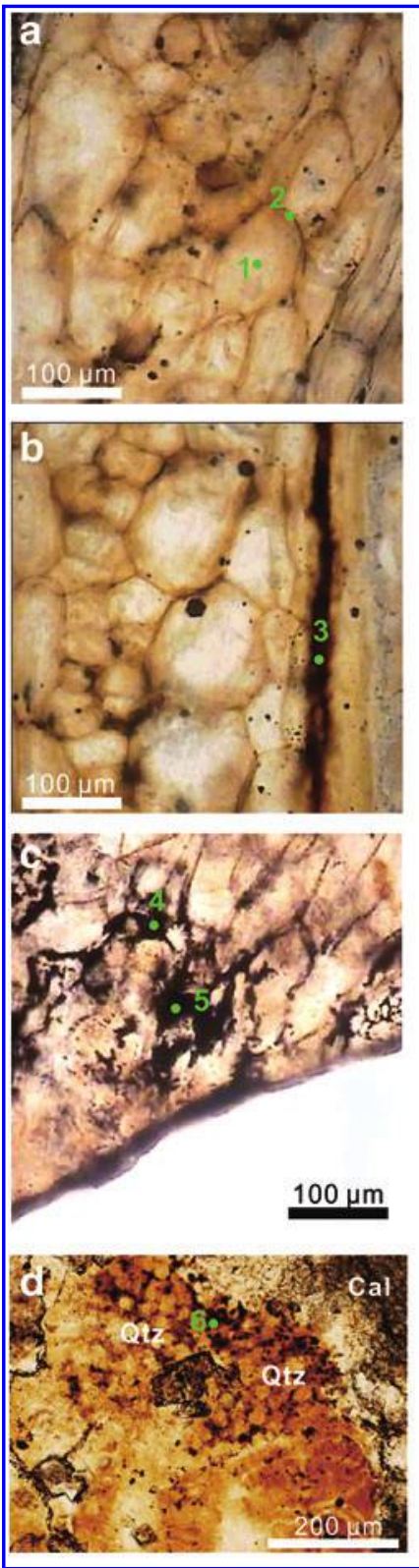

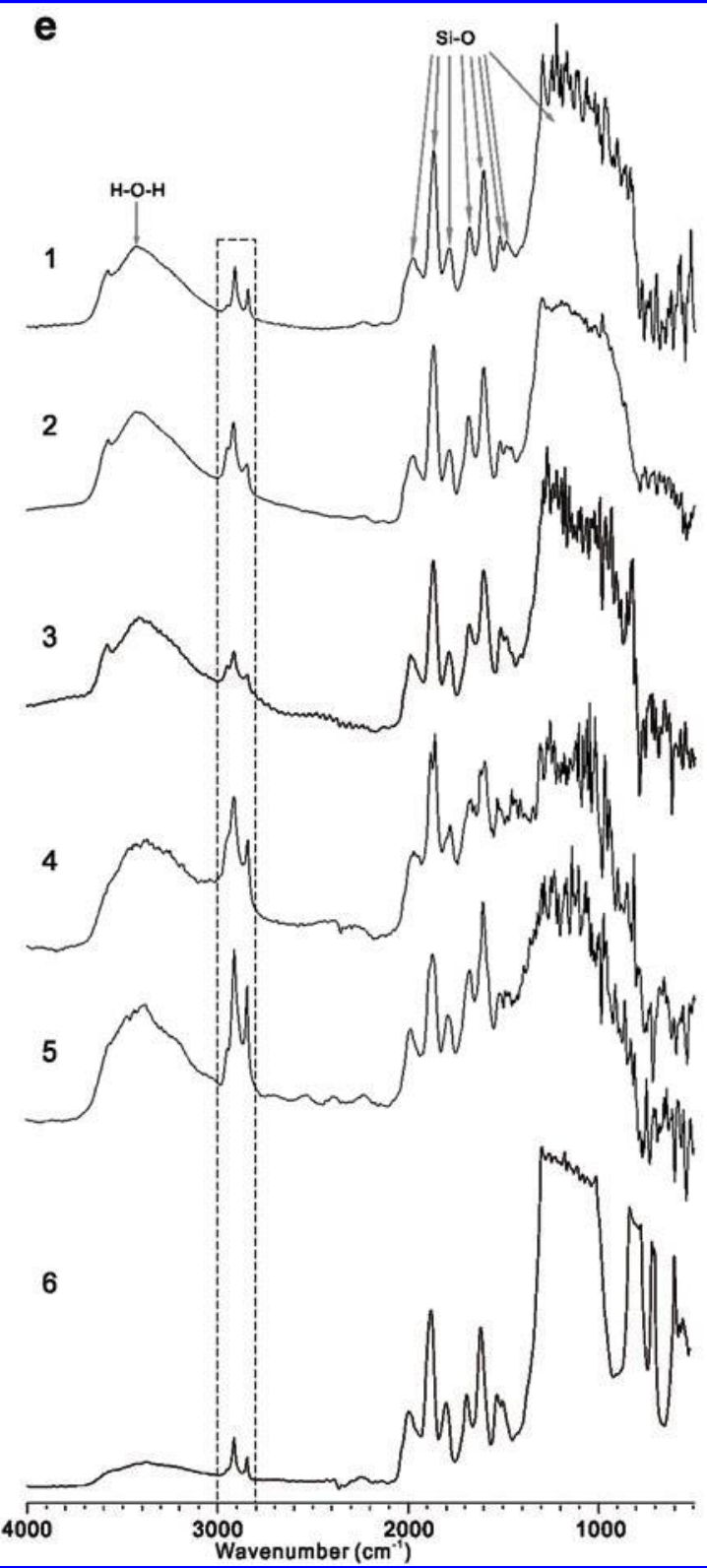

f

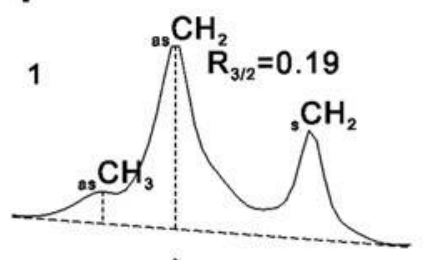

2

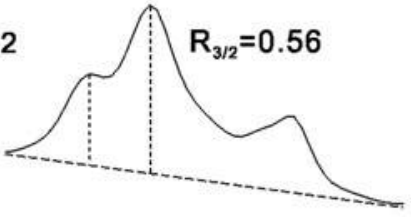

3
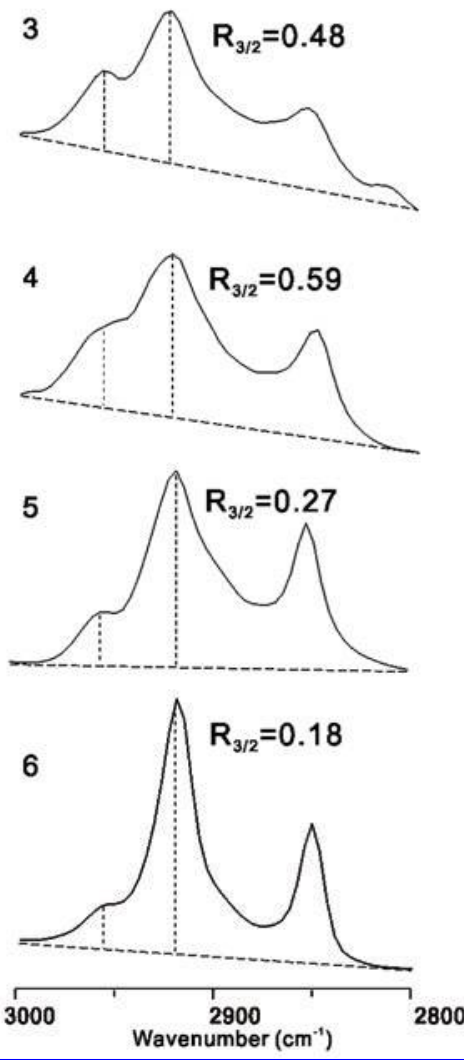

FIG. 8. Optical microscopic images and micro-FTIR spectra of fossils and CM from the Rhynie chert and Wumishan Formation. (a-d) Optical images of analyzed targets; the number spots show the location of measured IR spectra in (e) between 500 and $4000 \mathrm{~cm}^{-1}$, with the dashed boxed area enlarged in (f) focusing on peaks recording vibrations of the $-\mathrm{CH}_{2}$ and $-\mathrm{CH}_{3}$ groups and the $R_{3 / 2}$ intensity ratio reflecting the degree of carbon chain branching. Spectra 1 and 2 are obtained from fossilized protoplasm and cell wall of plant stem, respectively, from Rhynie chert. Spectrum 3 is from the epidermis of plant stem from Rhynie chert. Spectra 4 and 5 are from formless extracellular CM within the plant stem from Rhynie chert. Spectrum 6 is from CM in Wumishan microdigitate stromatolite. (Color graphics available at www.liebertonline.com/ast)

temperature estimate is obtained by RA1- and RA2-based calculations and gives peak-metamorphic temperatures in the range of $190-310^{\circ} \mathrm{C}, 150-350^{\circ} \mathrm{C}$, and $205-270^{\circ} \mathrm{C}$, respectively (Supplementary Figs. S1-S3). However, given that the fossil remains are particularly well preserved in the Rhynie chert and Bitter Springs samples, it is expected that the samples experienced only advanced diagenesis, with peak temperatures of around $200^{\circ} \mathrm{C}$, and at this temperature range the parameter R2 (Beyssac et al., 2002) is known not to be a suitable geothermometer. Moreover, in a study by Lahfid et al. (2010) the Raman spectra in the range of $1000-1500 \mathrm{~cm}^{-1}$ comprised the D4-, D1-, and D3-bands; however, in our study there is also a D5- band at around $1430 \mathrm{~m}^{-1}$ and another peak at around $1170 \mathrm{~m}^{-1}$ (Fig. 2b), which could affect the areas of the D4-, D1-, and D3-bands; thus the RA1 and RA2 may again be inaccurate parameters for assessing the structural order of CM in our samples.

Most of the Raman spectra obtained in this study are similar in the range of $1000-1500 \mathrm{~cm}^{-1}$ but differ in the range of $1500-1800 \mathrm{~cm}^{-1}$ due to differences in the G- and D2-bands (Figs. 3 and 4). In amorphous CM, the G-band is derived not only from hexatomic rings but also from $\mathrm{E}_{2 \mathrm{~g}}$ mode vibration of $\mathrm{sp}^{2}$ bond in carbon chains (Ferrari and Robertson, 2000); therefore the FWHM-D2 parameter is better than FWHM-G to describe the structural order of $\mathrm{CM}$ in our samples. 
In previous studies, the intensity ratio of $1350 \mathrm{~cm}^{-1}$ / $1600 \mathrm{~cm}^{-1}$ band was applied to evaluate the structural order of CM (Tuinstra and Koenig, 1970; Bonal et al., 2006; Kouketsu et al., 2014; Sforna et al., 2014a). If the peak metamorphic temperature is above c. $360^{\circ} \mathrm{C}$, the intensity ratio of $1350 \mathrm{~cm}^{-1}$ - versus $1600 \mathrm{~cm}^{-1}$-band (defined as $I$ $1350 / 1600)$ decreases as the structural order increases, whereas at temperatures $<360^{\circ} \mathrm{C}$, lower $I-1350 / 1600$ indicates lower structural order of CM (Kouketsu et al., 2014; Sforna et al., 2014a). In this study, the decomposition approached explained in Fig. 2a best avoids potential errors in decomposition and peak-fitting of the spectra into D1-, D2-, D3-, D4-, D5-, and G-bands (the way in Fig. 2b). Consequently, $I-1350 / 1600$ is the best parameter to assess the structural characteristic of CM accurately in this research, although it cannot be used as a geothermometer.

To summarize, the Raman spectral parameters I-1350/ 1600 and FWHM-D2 are the most appropriate parameters to assess the structural order of CM in this study and will be used to interpret the geobiological significance of heterogeneities in the following discussion. We note that, at higher metamorphic conditions, the secondary geological effects are the predominant controls on the structural order of the carbonaceous matter; this is therefore commonly used as a geothermometer (Beyssac et al., 2002; Rahl et al., 2005; Lahfid et al., 2010; Kouketsu et al., 2014). However, even at high metamorphic temperature, it is possible that different carbon precursors could give rise to different efficiencies in graphitization and thermal alteration/maturation (e.g., Franklin, 1951; Bernard et al., 2007, 2010; Galvez et al., 2012). It is also possible that large differences in peak metamorphic temperature estimates of up to $70^{\circ} \mathrm{C}$ within one thin section that were previously attributed to errors in Raman spectra acquisition and calculation (Beyssac et al., 2002; Rahl et al., 2005; Aoya et al., 2010; Lahfid et al., 2010; Kouketsu et al., 2014) may in part be derived from diverse biological carbonaceous precursors.

\subsection{Interpreting ultrastructural heterogeneities in fossilized carbonaceous matter: distinguishing primary biological variation from secondary geological transformations}

Among the factors that control the structural order of CM, the peak metamorphic temperature is crucial (see previous section), but it cannot explain marked variation on the scale of a few millimeters or micrometers as observed in our samples (Figs. 3, 4, 6, 7). Differential shear deformation can influence the structural order of CM (Bustin et al., 1995) and has been observed in CM within contact and regional metamorphic rocks, which have experienced the same metamorphic temperature (Aoya et al., 2010) but differential shear stress. However, there is no evidence of strong shear deformation in the microfossils or CM in our samples; therefore shear deformation can be excluded as the origin of the ultrastructural heterogeneities. The possibility of polishing artifacts (Pasteris, 1989; Beyssac et al., 2003; Ammar and Rouzaud, 2012; Maslova et al., 2012) created during thin section preparation can also be excluded, because all the Raman spectra were obtained by focusing the laser beam on the CM underneath the polished surface to avoid this artificial ordering of the carbonaceous material.
The mineral matrix can also conceivably play a role in acting as a template that enhances graphitization efficiency on mineral contacts by forming graphite films that envelop the mineral grains and can thus lead to higher structural order on mineral surfaces than the adjacent mineral-free CM (van Zuilen et al., 2012). The efficiency of this mineral-templating effect varies between different minerals, for example, quartz and chlorite, and this effect was discovered in the $2.0 \mathrm{Ga}$ Zaonega Formation (Russia) where organic-rich fluids were generated and mobilized by contact metamorphism at temperatures above $300^{\circ} \mathrm{C}$ in an organic-rich siltstone/shale (van Zuilen et al., 2012). However, this rock type differs significantly from the cherts studied here, where all the organic remains have been permineralized by fine-grained silica. In this research, all the Raman spectra were measured from CM intimately associated with quartz matrix, and the permineralizing silica fluid was pervasive and uniformly affected all parts of the CM with which it came into contact. Therefore, the mineral templating effect cannot explain the ultrastructural heterogeneities observed in subcellular components. The $I$ 1350/1600 of CM (Figs. 6d, 6h, 61, 7d, 7h) does not correlate to the relative intensity of either the $1350 \mathrm{~cm}^{-1}$-band or $1600 \mathrm{~cm}^{-1}$-band (Figs. 6b, 6c, 6f, 6g, 6j, 6k, 7b, 7c, 7f, 7g), arguing that the structural order of $\mathrm{CM}$ within various cellular components does not correspond to their relative carbon versus mineral concentrations. Moreover, if the mineral templating effect could affect the structural order of CM in the samples in this study, the $\mathrm{CM}$ within mineral matrix (low $\mathrm{CM}$ abundance, e.g., protoplasm in Figs. 6b, 6c) should have higher structural order than that within CM-enriched components (e.g., cell walls in Figs. 6b, 6c). Contrarily, the CM in protoplasm is in fact more disordered than that in cell walls (Fig. 6d). This further negates the possibility of mineral templatinginduced ultrastructural heterogeneities of the $\mathrm{CM}$ studied here.

The structural and chemical properties of the carbonaceous precursor can affect the final structural order of CM preserved in sedimentary rocks due to different efficiencies of graphitization (Franklin, 1951; Bernard et al., 2010; Sforna et al., 2014a). In well-preserved fossils or CM-experienced lowgrade metamorphism, different chemical compounds in the original carbonaceous precursors can potentially induce distinct Raman spectra due to specific vibrational modes arising from different bonding in the primary organic molecules (Kouketsu et al., 2014). In another recent independent study, ultrastructural heterogeneities were discovered in silicified microfossils from the 700-800 Ma Draken Formation using a different Raman system and were also interpreted as an indication of a different carbon precursor (Foucher et al., 2015). Thus to summarize, after excluding other possible factors, it is reasonable to conclude that the ultrastructural heterogeneities measured in the fossils and CM studied here are caused by different organic carbon precursors that coexisted in the diverse primary ecosystems.

\subsection{Micro-FTIR spectral characteristics and micrometer-scale chemical heterogeneities of carbonaceous matter}

In this study, we build on previous FTIR studies of fossilized cells preserved in chert (e.g., Preston and Genge, 2010) by employing micro-FTIR in transmission mode, which has much higher spatial resolution and enabled us to 

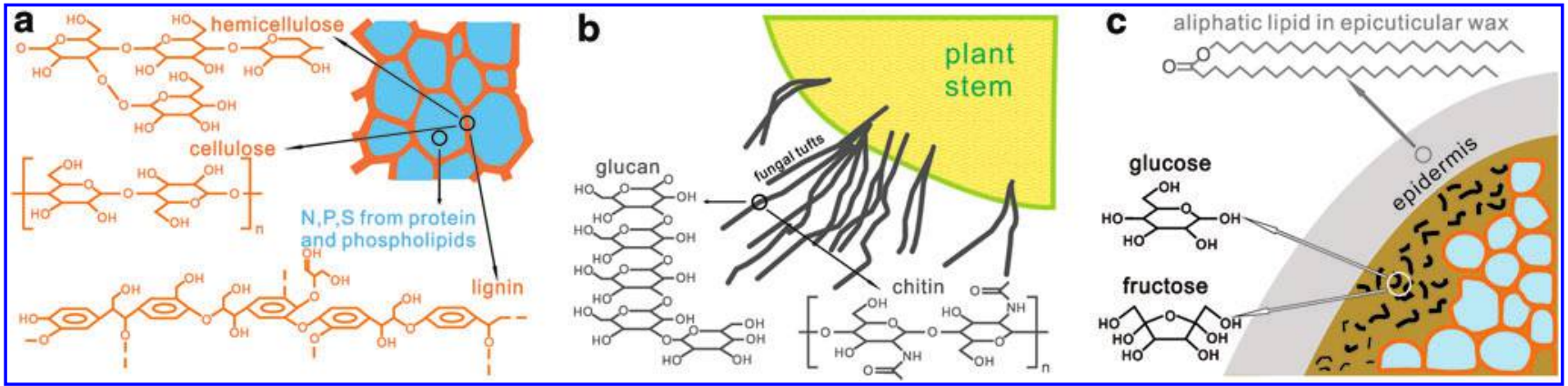

FIG. 9. Schematic interpretation illustrating the possible chemical compounds found in various carbonaceous precursors preserved in fossils and CM of the Rhynie chert. Note in particular their molecular structure, occurrence of heteroatoms, and degree of branching. (a) Cell wall (orange) and protoplasm (blue) of plant stem. (b) Fungal tufts and their host plant stem. (c) Formless extracellular CM (white circle) between cell walls and epidermis (gray circle). (Color graphics available at www.liebertonline.com/ast)

directly correlate IR spectral variation to the morphology of fossilized CM. In particular, we focus on the $R_{3 / 2}$ ratio of the IR spectra, which gives a measure of the branching index of carbon chains, or the relative ratio of $\mathrm{CH}_{3}$ versus $\mathrm{CH}_{2}$ carbon molecules; this in turn can be used to explore differences in the composition of CM. In the Rhynie chert, the fossilized plant protoplasm originally comprises an atrophic membrane, cytoplasm, organelles, and nuclei and yields low $R_{3 / 2}$ values, implying abundant straight-chain aliphatic carbon molecules derived from lipid compounds in the membrane (Figs. 8 and 9a, Supplementary Fig. S4). In comparison, the cell walls of the plant stems have higher $R_{3 / 2}$ values, probably due to more branched carbon molecules in the cellulose, hemicellulose, pectin, and lignin (Figs. 8 and 9a, Supplementary Fig. S4). The epidermis of plant stem consists of abundant aliphatic lipids in epicuticular wax; therefore the $R_{3 / 2}$ values are lower than the adjacent cell walls (Figs. 8 and 9c, Supplementary Fig. S4). The black formless extracellular $\mathrm{CM}$ has a large range of $R_{3 / 2}$ values (Fig. 8, Supplementary Fig. S4), suggesting multiple sources of organic compounds either from the local extracellular mucilage, the cytosol from lysed cells nearby, or compounds transported from other parts of the plant.

In the Wumishan stromatolites, the $R_{3 / 2}$ of CM derived from cyanobacteria shows a much narrower range (from 0.17 to 0.25, Fig. 8, Supplementary Fig. S4) compared to the Rhynie chert CM (from 0.19 to 0.61, Fig. 8, Supplementary Fig. S4), indicating more homogeneous carbon precursors predominantly sourced from prokaryotic cyanobacteria as opposed to eukaryotic matter. The micro-FTIR analysis has unfortunately not been performed on microfossils and CM from the Bitter Springs Formation in this study due to lack of available rock samples that could be prepared as doubly polished wafers. However, Igisu et al. (2006, 2009) studied microfossils from the Bitter Springs Formation by micro-FTIR, where the coccoidal (Glenobotrydion) and filamentous (Cephalophytarion) cyanobacteria have very similar $R_{3 / 2}$ ratios of 0.32 and 0.33 , respectively. This supports the idea of more homogeneous CM preserved within prokaryotes, comprising peptidoglycan and/ or glycoprotein of gelatin in cyanobacterial cell walls (Hoiczyk and Hansel, 2000; Smarda et al., 2002), regardless of different species and morphological occurrences. The undeveloped prokaryotic cell structures, organelles, and simpler metabolic functions compared to eukaryotes could explain the relatively homogeneous composition of fossils within the Wumishan stromatolites and the Bitter Springs samples.

To further investigate the potential correlation between the structural order of $\mathrm{CM}$ and the molecular structure of carbon precursors, the $I-1350 / 1600$ versus $R_{3 / 2}$ of fossils and CM from Rhynie chert, Bitter Springs, and Wumishan samples have been plotted together in Fig. 10. In the Rhynie

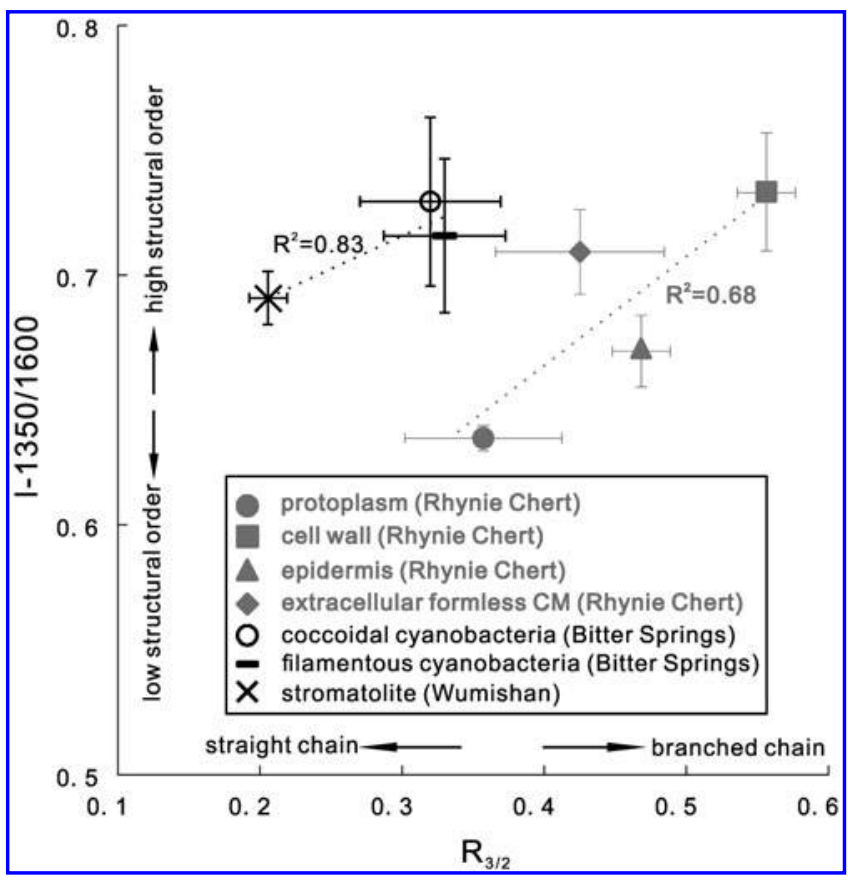

FIG. 10. Plots of degree of carbon chain branching $\left(R_{3 / 2}\right)$ calculated from IR spectra versus the degree of structural order (I-1350/1600) calculated from measured Raman spectra for CM from the Rhynie chert and Bitter Springs and Wumishan Formations. The average values with standard deviations are plotted. The dashed lines indicate a possible correlation between $R_{3 / 2}$ and $I-1350 / 1600$ of CM respectively inferred for eukaryotic plant material preserved in the Rhynie chert (gray dotted line), which shows a different trend from prokaryotic cyanobacteria in the Bitter Springs and Wumishan Formations (black dotted line). (Note the $R_{3 / 2}$ values of coccoidal and filamentous cyanobacteria in the Bitter Springs Formation are from the study of Igisu et al. (2009); all other values are based on our own spectroscopic measurements.) 
chert, both the $I-1350 / 1600$ and $R_{3 / 2}$ values show the lowest values in the protoplasm and the highest values in the cell wall, while the epidermis and extracellular formless CM have intermediate $I-1350 / 1600$ and $R_{3 / 2}$ values. Although only four different types of CM were compared, they record a positive correlation between $I-1350 / 1600$ and $R_{3 / 2}$ (Fig. 10). The cyanobacteria microfossils and CM in stromatolites from the Bitter Springs and Wumishan samples show a similar positive correlation between $I-1350 / 1600$ and $R_{3 / 2}$, implying that $\mathrm{CM}$ with lower $\mathrm{CH}_{3} / \mathrm{CH}_{2}$ ratio has lower structural order (Fig. 10). It is possible that aliphatic straight-chain carbon molecules (low $R_{3 / 2}$ ) are more difficult to be cyclized; thus they have lower efficiency in graphitization during postdepositional processes and consequently lower structural order than branched carbon chains.

Interestingly, the CM derived from eukaryotic plants in the Rhynie chert and prokaryotic cyanobacteria in the Bitter Springs and Wumishan samples show distinct correlations between $I-1350 / 1600$ and $R_{3 / 2}$ with different trends (Fig. 10), likely arising from differences between the eukaryotic and prokaryotic fossils. Indeed, it has been shown that extant eukaryotes, prokaryotes, and archaea have specific $R_{3 / 2}$ ranges; moreover $R_{3 / 2}$ even variates among different cellular compounds (lipid, membrane, protein, and the whole cell) of an individual species (cyanobacteria: Synechocystis) (Igisu et al., 2009). The selective preservation of lipids rather than protein and water-soluble compounds could influence the final whole cell- $R_{3 / 2}$ values; thus the fossilized cyanobacteria have different $R_{3 / 2}$ values compared to extant bacteria (Igisu et al., 2009).

In this study, the variation of $R_{3 / 2}$ in various $\mathrm{CM}$ and the correlation between $I-1350 / 1600$ and $R_{3 / 2}$ respectively in eukaryote-derived (Rhynie chert) and prokaryote-derived (Bitter Springs and Wumishan samples) CM probably reflect either the different compounds from the primary biomass or their differential degradation, preservation, and graphitization during the postdepositional processes. The detailed mechanism is still unknown, and more studies are needed.

\subsection{Biological interpretation of variations in the ultrastructure and chemistry of fossilized carbonaceous matter}

Chemical heterogeneities preserved within cell structures have previously been identified using electron microprobe mapping, for example, in fossilized plant stems and coexisting spores of the Rhynie chert (Boyce et al., 2001), which show similar spatial distribution of carbon as the Raman maps presented here but lack any information about ultrastructural order of the CM. In this study, we report Raman spectra that record ultrastructural variability in fossilized plant, fungi, and cyanobacteria and combine this with IR data that record chemical variability to discuss the biological significance of these results. Considering the Rhynie chert first, the cell walls of plants comprise cellulose, hemicellulose, pectin, and in many cases lignin (Buchanan et al., 2000), which are polymers of penta- and/or hexatomic-ring-based molecules such as D-glucose and aromatic derivants (Fig. 9a). These polysaccharides with cyclic-structured carbohydrate monomers could efficiently form graphene layers with hexagonal ring structures during postdepositional thermal alterations. In contrast, the protoplasm, including membrane, nucleus, cytosol, and all the organelles in the cytoplasm, contains abundant phosphorous lipids, protein, and nucleic acids with P, N, S, O, H (Fig. 9a, Buchanan et al., 2000). The abundant heteroatoms could hinder the cyclization of the hexatomic $\mathrm{C}$ rings; thus the structural order of the $\mathrm{CM}$ in protoplasm is predicted to be lower than that of cell walls (Figs. 3c and 6d, Supplementary Fig. S1).

The black formless extracellular $\mathrm{CM}$ in the phloem is probably derived from extracellular mucilage of phloem sap and records higher structural order than the adjacent cell walls of sclerenchyma (bast fibers) and the epidermis (Figs. 3d, 3e, and 61, Supplementary Fig. S1). The phloem sap, comprising mainly water with sugars, hormones, and mineral elements, is transported from the photosynthetic production areas to the nonphotosynthetic parts of the plant (Khan, 2001). The most abundant organic matter within phloem sap is sugar, which comprises monosaccharides with cyclic penta- and/or hexatomic molecular structures (e.g., glucose, fructose), whereas the epidermis consists of abundant straight-chain aliphatic hydrocarbons with a range of substituted functional groups in the epicuticular wax (Fig. 9c, Baker, 1982; Holloway and Jeffree, 2005). These chemical differences in the carbon precursors could result in lower efficiencies of graphitization and, thus, more disordered CM in the fossilized epidermis than the formless extracellular CM (Figs. 3e, 3f, and 61, Supplementary Fig. S1). The polysaccharide in the cell walls is highly polymerized compared to the sugars in phloem sap. It is unknown whether and how the degree of polymerization of monosaccharides could influence the final structural order of the CM. However, this could account for the ultrastructural differences between the formless extracellular CM and adjacent cell walls.

The CM of the fungal tufts has higher structural order than the fossilized cell walls of the host plant stem (Figs. 3i and 6h, Supplementary Fig. S1), and the CM embedded in the rhizoid has an intermediate structural order. Fungal cell walls are composed of chitin and glucan (Fig. 9b, Webster and Weber, 2007) containing polymers of cyclic molecules, for example, $\beta$ - $(1,4)$-linked- $N$-acetylglucosamine and $\mathrm{D}$ glucose, which differ strongly from cellulose, hemicellulose, and lignin in plant cell walls. This could explain the resultant ultrastructural heterogeneities between the carbonaceous material preserved in the fungal and plant cell walls.

The Raman spectra of prokaryotic cyanobacteria from the Bitter Springs samples do not show obvious cellular-scale structural heterogeneities within individual microfossils (Figs. 7d, 7h), probably due to the relatively simple cell structure and unspecified organelles as compared to eukaryotic cells. However, both coccoidal and filamentous microfossils do preserve heterogeneities in CM between microfossils (Figs. 4c, 4f, Supplementary Fig. S2), possibly indicating different compositions of organic matter in various species of cyanobacteria, or even in different growth stages. Both coccoidal and filamentous microfossils do not show systematic variations in structural order (Supplementary Fig. S2), implying that the predominant composition of the cyanobacterial cell walls is similar, comprising gelatin made of peptidoglycan and/or glycoprotein molecules (Hoiczyk and Hansel, 2000; Šmarda et al., 2002). Accordingly, the laminated (Fig. 4g) and clotted (Fig. 4h) CM in the surrounding chert matrix was probably also derived from coccoidal and/or filamentous cyanobacteria and preserved some limited structural 
heterogeneities but lacks systematic variation with morphology or microtexture (Supplementary Fig. S2). However, the ultrastructural heterogeneities within Precambrian prokaryotic microfossils could be well preserved and identified by Raman spectroscopy (e.g., map of $I-1350 / 1600)$, which indicates different carbon precursors rather than abiotic postdepositional processes (Foucher et al., 2015). This enables scientists to trace carbonaceous biosignatures from Precambrian cherts using Raman spectroscopy.

\subsection{Astrobiological implications}

Opaline silica has been discovered on the martian surface by the near-IR spectrometer on the Mars Reconnaissance Orbiter using CRISM (the Compact Reconnaissance Imaging Spectrometer for Mars) and by the Mini-TES (Thermal Emission Spectrometer) on the Spirit rover, and is interpreted as siliceous sinter deposits derived from hydrothermal activity (Glotch et al., 2006; Milliken et al., 2008; Squyres et al., 2008; Ruff et al., 2011). These siliceous deposits have been proposed as targets for exploration of biosignatures on Mars (e.g., McLennan et al., 2012), given that they suggest an aqueous environment at, or near, the martian surface and that silica is an excellent permineralizing agent and can preserve exceptional cellular details (Farmer and Des Marais, 1999; Cady et al., 2003). The ESA ExoMars rover scheduled for launch in 2018 will include a Raman spectrometer, the first such instrument to be deployed in space (Edwards et al., 2012). A UV-Raman spectrometer is also part of the SHERLOC (Scanning Habitable Environments with Raman and Luminescence for Organics and Chemicals) instrument in development for the NASA Mars 2020 mission. The overall goal of the ExoMars mission is to pave the way for Mars sample return and, in particular, focus on finding well-preserved organic remains. The payload also contains a MicrOmega near-IR spectrometer and MOMA (Mars Organic Molecule Analyzer), which is designed to target potential organic biomarkers. The Raman instrument has been advocated as an excellent tool for rapidly screening samples for organic remains that can then be analyzed by MOMA, which includes a gas chromatograph-mass spectrometer to test for biotic or abiotic compounds (e.g., Olcott Marshall and Marshall, 2014). Studies such as that reported here, which combine Raman and micro-FTIR spectroscopy to investigate carbonaceous biosignatures preserved in the rock record, are thus important for designing analysis strategies that could be employed on upcoming Mars rovers or in sample return missions.

Siliceous deposits bearing microfossils and organic carbon from the early rock record on Earth have been studied with Raman spectroscopy to investigate the preservation potential of carbonaceous remains and formulate potential biosignatures for martian exploration (e.g., Westall et al., 2011; Foucher and Westall, 2013). Siliceous hot spring deposits have also long been recognized as good target environments with high potential for biosignature preservation (e.g., Walter and Des Marais, 1993), where techniques such as Raman spectroscopy can help reconstruct the geological history and evaluate candidate biosignatures (e.g., Campbell and Abbey, 2012). In addition to silica minerals, Raman spectroscopy has been used to analyze other minerals that coexist with $\mathrm{CM}$, such as carbonate, pyrite, and apatite, whose specific bands in the Raman spectrum can also be analyzed to investigate putative mineral-microbial interactions (e.g., Igisu et al., 2014; Sforna et al., 2014b). Raman spectroscopy can be applied to analyze CM that has experienced thermal alteration, including higher-temperature metamorphism (Galvez et al., 2012; Kouketsu et al., 2014), which enables exploration of potential biosignatures in extreme environments on early Earth and Mars. Therefore, Raman spectroscopy is suggested as a roverbased technique for future exploration of possible microbial organics on Mars and for analyzing the returned rock samples (e.g., Wang et al., 2003; Rividi et al., 2010; McLennan et al., 2012). In summary, the combination of Raman and IR spectroscopy presented here is an efficient method with widespread application to the investigation of possible biosignatures on early Earth and Mars.

\section{Conclusions}

In this study, we report a combined Raman- and IRspectroscopy-based approach to investigating the origins and preservation of carbonaceous biosignatures. Raman spectroscopic analyses on well-preserved fossils and CM from the $410 \mathrm{Ma}$ Rhynie chert, the $820 \mathrm{Ma}$ Bitter Springs Formation, and the $1485 \mathrm{Ma}$ Wumishan Formation revealed heterogeneities in the ultrastructure of the organic matter derived from cellular-grade variations in the primary biomass. These cannot be explained by postdepositional geological processes but reflect cellular-scale heterogeneities in chemical composition of the carbon precursors, with different organic compounds that cause differential graphitization during thermal alteration.

Micro-FTIR analysis was used to quantify the branching index of the carbonaceous remains $\left(R_{3 / 2}\right)$ and combined with a Raman spectral parameter $(I-1350 / 1600)$, which describes the structural order of $\mathrm{CM}$. We found positive correlation between the branching index of carbon chain and the degree of structural order of various types of CM in both eukaryotic plant fossils (from the Rhynie chert) and cyanobacteriaderived CM (from the Bitter Springs and Wumishan stromatolites, Fig. 10). These two correlations in eukaryotes and prokaryotes imply that disordered CM has relatively more straight aliphatic carbon chains, but the organic compounds derived from eukaryotic and prokaryotic biomass probably behave differently during postdepositional processes.

Our research provides a guide to deciphering carbonaceous biosignatures preserved in siliceous deposits of early Earth and potentially Mars by investigating the ultrastructural and chemical characteristics of $\mathrm{CM}$ with a combination of Raman spectroscopy and micro-FTIR analysis.

\section{Acknowledgments}

Many thanks to Prof. M.D. Brasier and A.H. Knoll for loan and discussion of Rhynie chert and Bitter Springs samples. We thank P. Hands for making fluid inclusion wafers for FTIR analysis. We appreciate the discussions within the COST Action TD 1308. This work was financially supported by the University of Bergen and the Bergen Research Foundation by a grant to Dr. Nicola McLoughlin.

\section{Author Disclosure Statement}

Hereby we confirm that no competing financial interests exist. 


\section{References}

Aines, R.D. and Rossman, G.R. (1984) Water in minerals-a peak in the infrared. J Geophys Res 89:4059-4071.

Ammar, M. and Rouzaud, J.N. (2012) How to obtain a reliable structural characterization of polished graphitized carbons by Raman microspectroscopy. J Raman Spectrosc 43:207-211.

Aoya, M., Kouketsu, Y., Endo, S., Shimizu, H., Mizukami, T., Nakamura, D., and Wallis, S. (2010) Extending the applicability of the Raman carbonaceous-material geothermometer using data from contact metamorphic rocks. Journal of Metamorphic Geology 28:895-914.

Baker, E. (1982) Chemistry and morphology of plant epicuticular waxes. Linnean Society symposium series. In The Plant Cuticle, edited by D.F. Cutler, K.L. Alvin, and C.E. Price, Academic Press, London, pp 139-165.

Bellamy, L., editor. (1954) The Infra-Red Spectra of Complex Molecules, John Wiley \& Sons, New York, pp 13-56.

Bernard, S., Benzerara, K., Beyssac, O., Menguy, N., Guyot, F., Brown, G.E., and Goffe, B. (2007) Exceptional preservation of fossil plant spores in high-pressure metamorphic rocks. Earth Planet Sci Lett 262:257-272.

Bernard, S., Beyssac, O., Benzerara, K., Findling, N., Tzvetkov, G., and Brown, G.E., Jr. (2010) XANES, Raman and XRD study of anthracene-based cokes and saccharose-based chars submitted to high-temperature pyrolysis. Carbon 48:25062516.

Beyssac, O., Goffé, B., Chopin, C., and Rouzaud, J.N. (2002) Raman spectra of carbonaceous material in metasediments: a new geothermometer. Journal of Metamorphic Geology 20:859-871.

Beyssac, O., Goffé, B., Petitet, J., Froigneux, E., Moreau, M., and Rouzaud, J.N. (2003) On the characterization of disordered and heterogeneous carbonaceous materials by Raman spectroscopy. Spectrochim Acta A Mol Biomol Spectrosc 59:2267-2276.

Bonal, L., Quirico, E., Bourot-Denise, M., and Montagnac, G. (2006) Determination of the petrologic type of CV3 chondrites by Raman spectroscopy of included organic matter. Geochim Cosmochim Acta 70:1849-1863.

Boyce, C., Hazen, R., and Knoll, A. (2001) Nondestructive, in situ, cellular-scale mapping of elemental abundances including organic carbon in permineralized fossils. Proc Natl Acad Sci USA 98:5970-5974.

Buchanan, B.B., Gruissem, W., and Jones, R.L. (2000) Biochemistry \& Molecular Biology of Plants, American Society of Plant Physiologists, Rockville, MD.

Buseck, P.R., Bo-Jun, H., and Keller, L.P. (1987) Electron microscope investigation of the structures of annealed carbons. Energy and Fuels 1:105-110.

Bustin, R.M., Ross, J.V., and Rouzaud, J.N. (1995) Mechanisms of graphite formation from kerogen: experimental evidence. Int J Coal Geol 28:1-36.

Cady, S.L., Farmer, J.D., Grotzinger, J.P., Schopf, J.W., and Steele, A. (2003) Morphological biosignatures and the search for life on Mars. Astrobiology 3:351-368.

Campbell, V. and Abbey, W. (2012) Raman mapping of Mars relevant minerals using multiple excitation wavelengths. In STAR Program, NASA Jet Propulsion Laboratory, Pasadena, CA.

Croft, W.N. and George, E.A. (1959) Blue-Green Algae from the Middle Devonian of Rhynie, Aberdeenshire, British $\mathrm{Mu}-$ seum (Natural History), London.

Des Marais, D.J. (2001) Isotopic evolution of the biogeochemical carbon cycle during the Precambrian. Reviews in Mineralogy and Geochemistry 43:555-578.
Edgoose, C.J. (2012) The Amadeus Basin, central Australia. Episodes 35:256-263.

Edwards, D.S. (1986) Aglaophyton major, a non-vascular landplant from the Devonian Rhynie chert. Bot J Linn Soc 93:173-204.

Edwards, D.S. and Lyon, A.G. (1983) Algae from the Rhynie chert. Bot J Linn Soc 86:37-55.

Edwards, H.G., Hutchinson, I., and Ingley, R. (2012) The ExoMars Raman spectrometer and the identification of biogeological spectroscopic signatures using a flight-like prototype. Anal Bioanal Chem 404:1723-1731.

Farmer, J.D. and Des Marais, D.J. (1999) Exploring for a record of ancient martian life. J Geophys Res: Planets 104:2697726995.

Fayers, S.R. and Trewin, N.H. (2002) A new crustacean from the Early Devonian Rhynie chert, Aberdeenshire, Scotland. Earth Environ Sci Trans $R$ Soc Edinb 93:355-382.

Ferrari, A.C. and Robertson, J. (2000) Interpretation of Raman spectra of disordered and amorphous carbon. Phys Rev B 61:14095-14107.

Foucher, F. and Westall, F. (2013) Raman imaging of metastable opal in carbonaceous microfossils of the 700-800 Ma Old Draken Formation. Astrobiology 13:57-67.

Foucher, F., Ammar, M.R., and Westall, F. (2015) Revealing the biotic origin of silicified Precambrian carbonaceous microstructures using Raman spectroscopic mapping, a potential method for the detection of microfossils on Mars. J Raman Spectrosc [Epub ahead of print: doi: 10.1002/jrs .4687].

Franklin, R.E. (1951) Crystallite growth in graphitizing and non-graphitizing carbons. Philos Transact A Math Phys Eng Sci 209:196-218.

Galvez, M., Beyssac, O., Benzerara, K., Bernard, S., Menguy, N., Cox, S., Martinez, I., Johnston, M., and Brown, G. (2012) Morphological preservation of carbonaceous plant fossils in blueschist metamorphic rocks from New Zealand. Geobiology 10:118-129.

Galvez, M.E., Beyssac, O., Martinez, I., Benzerara, K., Chaduteau, C., Malvoisin, B., and Malavieille, J. (2013) Graphite formation by carbonate reduction during subduction. Nat Geosci 6:473-477.

Glikson, A.Y., Stewart, A.J., Ballhaus, C.G., Clarke, G.L., Feeken, E.H.J., Leven, J.H., Sheraton, J.W., and Sun, S.S. (1996) Geology of the Western Musgrave Block, Central Australia, with Particular Reference to the Maficultramafic Giles Complex, Bulletin 239, Australian Geological Survey Organisation, Canberra.

Glotch, T.D., Bandfield, J.L., Christensen, P.R., Calvin, W.M., McLennan, S.M., Clark, B.C., Rogers, A.D., and Squyres S.W. (2006) Mineralogy of the light-toned outcrop at Meridiani Planum as seen by the Miniature Thermal Emission Spectrometer and implications for its formation. J Geophys Res: Planets 111, doi:10.1029/2005JE002672.

Grassineau, N., Abell, P., Appel, P., Lowry, D., and Nisbet, E. (2006) Early life signatures in sulfur and carbon isotopes from Isua, Barberton, Wabigoon (Steep Rock), and Belingwe Greenstone Belts (3.8 to $2.7 \mathrm{Ga}$ ). Geological Society of America Memoirs 198:33-52.

Hayes, J.M. and Waldbauer, J.R. (2006) The carbon cycle and associated redox processes through time. Philos Trans $R$ Soc Lond B Biol Sci 361:931-950.

Hoiczyk, E. and Hansel, A. (2000) Cyanobacterial cell walls: news from an unusual prokaryotic envelope. J Bacteriol 182: 1191-1199. 
Holloway, P. and Jeffree, C. (2005) Epicuticular waxes. Encyclopedia of Applied Plant Sciences 3:1190-1204.

House, C.H., Schopf, J.W., McKeegan, K.D., Coath, C.D., Harrison, T.M., and Stetter, K.O. (2000) Carbon isotopic composition of individual Precambrian microfossils. Geology 28:707-710.

Igisu, M., Nakashima, S., Ueno, Y., Awramik, S.M., and Maruyama, S. (2006) In situ infrared microspectroscopy of 850 millionyear-old prokaryotic fossils. Appl Spectrosc 60:1111-1120.

Igisu, M., Ueno, Y., Shimojima, M., Nakashima, S., Awramik, S.M., Ohta, H., and Maruyama, S. (2009) Micro-FTIR spectroscopic signatures of bacterial lipids in Proterozoic microfossils. Precambrian Res 173:19-26.

Igisu, M., Komiya, T., Kawashima, M., Nakashima, S., Ueno, Y., Han, J., Shu, D., Li, Y., Guo, J., and Maruyama, S. (2014) FTIR microspectroscopy of Ediacaran phosphatized microfossils from the Doushantuo Formation, Weng'an, South China. Gondwana Research 25:1120-1138.

Ito, Y. and Nakashima, S. (2002) Water distribution in lowgrade siliceous metamorphic rocks by micro-FTIR and its relation to grain size: a case from the Kanto Mountain region, Japan. Chem Geol 189:1-18.

Javaux, E.J. and Marshall, C.P. (2006) A new approach in deciphering early protist paleobiology and evolution: combined microscopy and microchemistry of single Proterozoic acritarchs. Rev Palaeobot Palynol 139:1-15.

Javaux, E.J., Marshall, C.P., and Bekker, A. (2010) Organicwalled microfossils in 3.2-billion-year-old shallow-marine siliciclastic deposits. Nature 463:934-938.

Jehlička, J., Urban, O., and Pokorný, J. (2003) Raman spectroscopy of carbon and solid bitumens in sedimentary and metamorphic rocks. Spectrochim Acta A Mol Biomol Spectrosc 59:2341-2352.

Khan, A. (2001) Plant Anatomy and Physiology, Gyan Publishing House, Delhi.

Kidston, R. and Lang, W. (1920a) XXVI.-On old red sandstone plants showing structure, from the Rhynie chert bed, Aberdeenshire. Part III. Asteroxylon mackiei, Kidston and Lang. Transactions of the Royal Society of Edinburgh 52:643-680.

Kidston, R. and Lang, W.H. (1920b) XXIV. On old red sandstone plants showing structure, from the Rhynie chert bed, Aberdeenshire. Part II. Additional notes on Rhynia gwynnevaughani, Kidston and Lang; with descriptions of Rhynia major, n. sp., and Hornea lignieri, ng, n. sp. Transactions of the Royal Society of Edinburgh 52:603-627.

Knoll, A.H. and Golubic, S. (1979) Anatomy and taphonomy of a Precambrian algal stromatolite. Precambrian Res 10:115-151.

Kouketsu, Y., Mizukami, T., Mori, H., Endo, S., Aoya, M., Hara, H., Nakamura, D., and Wallis, S. (2014) A new approach to develop the Raman carbonaceous material geothermometer for low-grade metamorphism using peak width. Island Arc 23:33-50.

Kremer, B., Owocki, K., Królikowska, A., Wrzosek, B., and Kazmierczak, J. (2012) Mineral microbial structures in a bone of the Late Cretaceous dinosaur Saurolophus angustirostris from the Gobi Desert, Mongolia—a Raman spectroscopy study. $\mathrm{Pa}$ laeogeogr Palaeoclimatol Palaeoecol 358:51-61.

Lahfid, A., Beyssac, O., Deville, E., Negro, F., Chopin, C., and Goffe, B. (2010) Evolution of the Raman spectrum of carbonaceous material in low-grade metasediments of the Glarus Alps (Switzerland). Terra Nova 22:354-360.

Lepland, A., van Zuilen, M.A., and Philippot, P. (2011) Fluid deposited graphite and its geobiological implications in early Archean gneiss from Akilia, Greenland. Geobiology 9:2-9.
Lepot, K., Benzerara, K., Rividi, N., Cotte, M., Brown, G.E., Jr., and Philippot, P. (2009) Organic matter heterogeneities in $2.72 \mathrm{Ga}$ stromatolites: alteration versus preservation by sulfur incorporation. Geochim Cosmochim Acta 73:6579-6599.

Li, H., Su, W., Zhou, H., Xiang, Z., Tian, H., Yang, L., Huff, W., and Ettensohn, F. (2014) The first precise age constraints on the Jixian System of the Meso- to Neoproterozoic Standard Section of China: SHRIMP zircon U-Pb dating of bentonites from the Wumishan and Tieling formations in the Jixian Section, North China Craton. Acta Petrologica Sinica 30:2999-3012.

Liang, Y., Cao, R., Zhang, L., Qiu, Y., Xiao, Z., Cao, R., Duan, J., Du, R., Bu, D., and Gao, Z. (1984) Stromatolites of Pseupogymnosolenidae from late Precambrian in China. Science China Press (B), 59-72.

Liang, Y., Zhu, S., Zhang, L., Cao, R., Gao, Z., and Bu, D.A. (1985) Stromatolite assemblages of the Late Precambrian in China. Precambrian Res 29:15-32.

Luque, F.J., Barrenechea, J.F., Millward, D., Beyssac, O., and Huizenga, J. (2009) Deposition of highly crystalline graphite from moderate-temperature fluids. Geology 37:275-278.

Marshall, C.P. and Olcott Marshall, A. (2011) Hematite and carbonaceous materials in geological samples: a cautionary tale. Spectrochim Acta A Mol Biomol Spectrosc 80:133-137.

Marshall, C.P. and Olcott Marshall, A. (2013) Raman hyperspectral imaging of microfossils: potential pitfalls. Astrobiology 13:920-931.

Marshall, C.P. and Olcott Marshall, A. (2014) Raman spectroscopy as a screening tool for ancient life detection on Mars. Philos Transact A Math Phys Eng Sci 372, doi:10.1098/ rsta.2014.0195.

Marshall, C.P., Javaux, E.J., Knoll, A.H., and Walter, M.R. (2005) Combined micro-Fourier transform infrared (FTIR) spectroscopy and micro-Raman spectroscopy of Proterozoic acritarchs: a new approach to palaeobiology. Precambrian Res 138:208-224.

Marshall, C.P., Emry, J.R., and Marshall, A.O. (2011) Haematite pseudomicrofossils present in the 3.5-billion-year-old Apex chert. Nat Geosci 4:240-243.

Maslova, O., Ammar, M., Guimbretière, G., Rouzaud, J.N., and Simon, P. (2012) Determination of crystallite size in polished graphitized carbon by Raman spectroscopy. Phys Rev B 86, doi:10.1103/PhysRevB.86.134205.

Mayo, D.W., Miller, F.A., and Hannah, R.W., editors. (2004) Course Notes on the Interpretation of Infrared and Raman Spectra, Wiley Online Library, Hoboken, NJ.

McLennan, S.M., Sephton, M.A., Allen, C., Allwood, A.C., Barbieri, R., Beaty, D.W., Boston, P., Carr, M., Grady, M., Grant, J., Heber, V.S., Herd, C.D.K., Hofmann, B., King, P., Mangold, N., Ori, G.G., Rossi, A.P., Raulin, F., Ruff, S.W., Sherwood Lollar, B., Symes, S., and Wilson, M.G. (2012) Planning for Mars returned sample science: final report of the MSR End-to-End International Science Analysis Group (E2E-iSAG). Astrobiology 12:175-230.

Mei, M., Ma, Y., and Guo, Q. (2001a) Facies-fabric features of the Wumishan cyclothems and their Markov chain analysis at the Jixian section in Tianjin. Geological Journal of China Universities 7:288-299.

Mei, M., Ma, Y., and Zhou, H. (2001b) Fischer plot of the Wumishan cyclotherms and their application to define the third-order sea-level changes of the Precambrian. Acta Geoscientica Sinica 22:429-436.

Mei, M., Gao, J., Meng, Q., and Liu, Z. (2008) Microdigital stromatolites and their response to stromatolite decline at 
$1250 \mathrm{Ma}$ for the Mesoproterozoic Wumishan Formation at Jixian section in Tianjin. Journal of Palaeogeography 10: 495-509.

Milliken, R.E., Swayze, G.A., Arvidson, R.E., Bishop, J.L., Clark, R.N., Ehlmann, B.L., Green, R.O., Grotzinger, J.P., Morris, R.V., Murchie, S.L., Mustard, J.F., and Weitz, C. (2008) Opaline silica in young deposits on Mars. Geology $36: 847-850$.

Oehler, D.Z. and Cady, S.L. (2014) Biogenicity and syngeneity of organic matter in ancient sedimentary rocks: recent advances in the search for evidence of past life. Challenges 5:260-283.

Olcott Marshall, A. and Marshall, C.P. (2014) Vibrational spectroscopy of fossils. Palaeontology 58:201-211.

Olcott Marshall, A., Corsetti, F.A., Sessions, A.L., and Marshall, C.P. (2009) Raman spectroscopy and biomarker analysis reveal multiple carbon inputs to a Precambrian glacial sediment. Org Geochem 40:1115-1123.

Olcott Marshall, A., Jehlička, J., Rouzaud, J.N., and Marshall, C.P. (2014) Multiple generations of carbonaceous material deposited in Apex chert by basin-scale pervasive hydrothermal fluid flow. Gondwana Research 25:284-289.

Parry, S., Noble, S., Crowley, Q., and Wellman, C. (2011) A high-precision $\mathrm{U}-\mathrm{Pb}$ age constraint on the Rhynie chert Konservat-Lagerstätte: time scale and other implications. $\underline{J}$ Geol Soc London 168:863-872.

Pasteris, J.D. (1989) In situ analysis in geological thin-sections by laser Raman microprobe spectroscopy: a cautionary note. Appl Spectrosc 43:567-570.

Pasteris, J.D. and Wopenka, B. (2003) Necessary, but not sufficient: Raman identification of disordered carbon as a signature of ancient life. Astrobiology 3:727-738.

Preston, L.J. and Genge, M.J. (2010) The Rhynie chert, Scotland, and the search for life on Mars. Astrobiology 10:549-560.

Qu, Y., Črne, A.E., Lepland, A., and van Zuilen, M.A. (2012) Methanotrophy in a Paleoproterozoic oil field ecosystem, Zaonega Formation, Karelia, Russia. Geobiology 10:467-478.

Rahl, J.M., Anderson, K.M., Brandon, M.T., and Fassoulas, C. (2005) Raman spectroscopic carbonaceous material thermometry of low-grade metamorphic rocks: calibration and application to tectonic exhumation in Crete, Greece. Earth Planet Sci Lett 240:339-354.

Remy, W., Taylor, T.N., and Hass, H. (1994a) Early Devonian fungi: a blastocladalean fungus with sexual reproduction. $\underline{\mathrm{Am}}$ J Bot 81:690-702.

Remy, W., Taylor, T.N., Hass, H., and Kerp, H. (1994b) Four hundred-million-year-old vesicular arbuscular mycorrhizae. Proc Natl Acad Sci USA 91:11841-11843.

Rice, C., Ashcroft, W., Batten, D., Boyce, A., Caulfield, J., Fallick, A., Hole, M., Jones, E., Pearson, M., and Rogers, G. (1995) A Devonian auriferous hot spring system, Rhynie, Scotland. J Geol Soc London 152:229-250.

Rice, C., Trewin, N., and Anderson, L. (2002) Geological setting of the Early Devonian Rhynie cherts, Aberdeenshire, Scotland: an early terrestrial hot spring system. London 159:203-214.

Rividi, N., van Zuilen, M., Philippot, P., Menez, B., Godard, G., and Poidatz, E. (2010) Calibration of carbonate composition using micro-Raman analysis: application to planetary surface exploration. Astrobiology 10:293-309.

Romero-Sarmiento, M.F., Rouzaud, J.N., Bernard, S., Deldicque, D., Thomas, M., and Littke, R. (2014) Evolution of Barnett Shale organic carbon structure and nanostructure with increasing maturation. Org Geochem 71:7-16.
Ross, J.V. and Bustin, R.M. (1990) The role of strain energy in creep graphitization of anthracite. Nature 343:58-60.

Ruff, S.W., Farmer, J.D., Calvin, W.M., Herkenhoff, K.E., Johnson, J.R., Morris, R.V., Rice, M.S., Arvidson, R.E., Bell, J.F., Christensen, P.R., and Squyres, S.W. (2011) Characteristics, distribution, origin, and significance of opaline silica observed by the Spirit rover in Gusev Crater, Mars. J Geophys Res: Planets 116, doi:10.1029/2010JE003767.

Sadezky, A., Muckenhuber, H., Grothe, H., Niessner, R., and Pöschl, U. (2005) Raman microspectroscopy of soot and related carbonaceous materials: spectral analysis and structural information. Carbon 43:1731-1742.

Satterthwait, D.F. and Schopf, J.W. (1972) Structurally preserved phloem zone tissue in Rhynia. Am J Bot 59:373-376.

Schidlowski, M. (2001) Carbon isotopes as biogeochemical recorders of life over $3.8 \mathrm{Ga}$ of Earth history: evolution of a concept. Precambrian Res 106:117-134.

Schopf, J.W. (1968) Microflora of the Bitter Springs Formation, late Precambrian, central Australia. J Paleontol 42: 651-688.

Schopf, J.W. (2006) Fossil evidence of Archaean life. Philos Trans $R$ Soc Lond B Biol Sci 361:869-885.

Schopf, J.W. and Blacic, J.M. (1971) New microorganisms from the Bitter Springs Formation (late Precambrian) of the northcentral Amadeus Basin, Australia. J Paleontol 45:925-960.

Schopf, J. and Kudryavtsev, A. (2005) Three-dimensional Raman imagery of Precambrian microscopic organisms. Geobiology $3: 1-12$.

Schopf, J.W. and Kudryavtsev, A.B. (2009) Confocal laser scanning microscopy and Raman imagery of ancient microscopic fossils. Precambrian Res 173:39-49.

Sforna, M., van Zuilen, M., and Philippot, P. (2014a) Structural characterization by Raman hyperspectral mapping of organic carbon in the 3.46 billion-year-old Apex chert, Western Australia. Geochim Cosmochim Acta 124:18-33.

Sforna, M.C., Philippot, P., Somogyi, A., van Zuilen, M.A., Medjoubi, K., Schoepp-Cothenet, B., Nitschke, W., and Visscher, P.T. (2014b) Evidence for arsenic metabolism and cycling by microorganisms 2.7 billion years ago. Nat Geosci 7:811-815. Šmarda, J., Smajs, D., Komrska, J., and Krzyžánek, V. (2002) S-layers on cell walls of cyanobacteria. Micron 33:257-277. Squyres, S.W., Arvidson, R.E., Ruff, S., Gellert, R., Morris, R.V., Ming, D.W., Crumpler, L., Farmer, J.D., Des Marais, D.J., Yen, A., McLennan, S.M., Calvin, W., Bell, J.F., III, Clark, B.C., Wang, A., McCoy, T.J., Schmidt, M.E., and de Souza, P.A., Jr. (2008) Detection of silica-rich deposits on Mars. Science 320:1063-1067.

Taylor, T., Hass, H., and Kerp, H. (1997) A cyanolichen from the Lower Devonian Rhynie chert. Am J Bot 84:992.

Taylor, T.N., Klavins, S.D., Krings, M., Taylor, E.L., Kerp, H., and Hass, H. (2004) Fungi from the Rhynie chert: a view from the dark side. Trans $R$ Soc Edinb Earth Sci 94:457-473.

Trewin, N.H. (1993) Depositional environment and preservation of biota in the Lower Devonian hot-springs of Rhynie, Aberdeenshire, Scotland. Trans R Soc Edinb Earth Sci 84:433-442.

Tuinstra, F. and Koenig, J.L. (1970) Raman spectrum of graphite. J Chem Phys 53, doi:10.1063/1.1674108.

van Zuilen, M.A., Chaussidon, M., Rollion-Bard, C., and Marty, B. (2007) Carbonaceous cherts of the Barberton Greenstone Belt, South Africa: isotopic, chemical and structural characteristics of individual microstructures. Geochim Cosmochim Acta 71:655-669.

van Zuilen, M.A, Fliegel, D., Wirth, R., Lepland, A., Qu, Y., Schreiber, A., Romashkin, A.E., and Philippot, P. (2012) 
Mineral-templated growth of natural graphite films. Geochim Cosmochim Acta 83:252-262.

Walter, M.R. and Des Marais, D.J. (1993) Preservation of biological information in thermal-spring deposits - developing a strategy for the search for fossil life on Mars. Icarus 101:129-143.

Wang, A., Haskin, L.A., Lane, A.L., Wdowiak, TJ., Squyres, S.W., Wilson, R.J., Hovland, L.E., Manatt, K.S., Raouf, N., and Smith, C.D. (2003) Development of the Mars microbeam Raman spectrometer (MMRS). J Geophys Res 108(E1):5005, doi: 10.1029/2002JE001902.

Webster, J., and Weber, R., editors. (2007) Introduction to Fungi, Cambridge University Press, Cambridge, UK.

Wellman, C.H. (2004) Palaeoecology and palaeophytogeography of the Rhynie chert plants: evidence from integrated analysis of in situ and dispersed spores. Philos Trans $R$ Soc Lond B Biol Sci 271:985-992.

Wells, A.T., Forman, D., Ranford, L., and Cook, P., editors. (1970) Geology of the Amadeus Basin, Central Australia, Bulletin 100, Australian Bureau of Mineral Resources, Geology and Geophysics, Canberra.

Westall, F., Foucher, F., Cavalazzi, B., de Vries, S.T., Nijman, W., Pearson, V., Watson, J., Verchovsky, A., Wright, I., Rouzaud, J.-N., Marchesini, D., and Severine, A. (2011) Volcaniclastic habitats for early life on Earth and Mars: a case study from similar to 3.5 Ga-old rocks from the Pilbara, Australia. Planet Space Sci 59:1093-1106.

Whalley, P. and Jarzembowski, E. (1981) A new assessment of Rhyniella, the earliest known insect, from the Devonian of Rhynie, Scotland. Nature 291, doi:10.1038/291317a0.

Wopenka, B. and Pasteris, J.D. (1993) Structural characteristics of kerogens to granulite-facies graphite: applications of Raman microprobe spectroscopy. Am Mineral 78:533-557.
Yui, T.F., Huang, E., and Xu, J. (1996) Raman spectrum of carbonaceous material: a possible metamorphic grade indicator for low-grade metamorphic rocks. Journal of Metamorphic Geology 14:115-124.

Zhou, L., Zhao, C., and Liu, M. (1989) The environment significance of stromatolites in Wumishan Formation of Precambrian in western Yanshan mountains of north China. Journal of the University of Petroleum China 13:11-20.

Zhu, S., Liang, Y., and Du, R., editors. (1993) Stromatolites in China [in Chinese], Press of Tianjin University, Tianjin.

Zhu, S., Xing, Y., and Zhang, P., editors. (1994) Biostratigraphic Sequence of the Middle-Upper Proterozoic in NorthChina Platform [in Chinese], Beijing Geological Publishing House, Beijing.

Address correspondence to: Qu Yuangao

Department of Earth Science and Centre for Geobiology Allegaten 41 Bergen 5007

Norway

E-mail: qu_yuangao@hotmail.com

Submitted 5 February 2015

Accepted 27 July 2015

\begin{tabular}{rl|} 
& Abbreviations Used \\
$\mathrm{CM}=$ carbonaceous material \\
$\mathrm{FTIR}=$ Fourier transform infrared \\
$\mathrm{GC}-\mathrm{MS}=$ gas chromatography-mass spectrometry
\end{tabular}

